\title{
THE PHYLLOSILICATES IN DIAGENETIC-METAMORPHIC ROCKS OF THE SOUTH PORTUGUESE ZONE, SOUTHWESTERN PORTUGAL
}

\author{
ISABEL $\mathrm{ABAD}^{\S}$ \\ Instituto Andaluz de Ciencias de la Tierra, Universidad de Granada-CSIC, E-18002 Granada, Spain \\ MARIA PILAR MATA \\ Departamento de Geología, Facultad de Ciencias del Mar, Universidad de Cádiz, E-11510 Puerto Real (Cádiz), Spain \\ FERNANDO NIETO \\ Instituto Andaluz de Ciencias de la Tierra y Departamento de Mineralogía y Petrología, \\ Universidad de Granada, E-18002 Granada, Spain \\ NICOLAS VELILLA \\ Departamento de Mineralogía y Petrología, Facultad de Ciencias, Universidad de Granada, E-18002 Granada, Spain
}

\begin{abstract}
Devonian and Carboniferous metasedimentary sequences in the southernmost sector of the Iberian Massif, part of the Hercynian Orogen in southwestern Portugal, contain shales and slates of low but variable metamorphic grade. These rocks have been studied by optical microscopy and XRD to obtain basic data on their clay mineralogy and crystal-chemical parameters (IC, the index of "crystallinity", $b$ and $d_{001}$ ). Electron-microscopy techniques (SEM, HRTEM and AEM) have been used to characterize the textural relationships and chemical evolution of the minerals, mainly the phyllosilicates. A good correlation has been found between the data determined by XRD methods and by electron microscopy. The main mineral association is quartz + dioctahedral $\mathrm{K}$-rich mica + feldspars, but Na-K intermediate mica, paragonite, kaolinite and chlorite also are present, although discontinuously. The thickness of crystallites measured directly from lattice-fringe images is related to the IC, providing information on the evolution of the metamorphism through the sequences, with decreasing IC from southwest to northeast. The IC values for both the Brejeira and Mira formations correspond to diagenesis and anchizone, the Mértola and Phyllite-Quartzite formations, to high anchizone-epizone, and the Pulo do Lobo Formation presents values typical of epizonal conditions. Despite this pattern of evolution, however, the changes in metamorphic grade are not progressive, and the abrupt changes found between the characteristic values of each stratigraphic formation are interpreted as being associated with thrust surfaces. Textural data provide a clear contrast between the samples of different grade, with the lowest-grade samples showing a bedding-parallel microfabric and stacks of phyllosilicates. The most strongly metamorphosed pelites, on the other hand, present a crenulation-cleavage microfabric and a recrystallized matrix. As grade of metamorphism increases, crystal thickness increases and defects decrease in the phyllosilicates, although chlorite shows a higher density of strain-related defects than mica. There is wide scatter in the chemical data for both dioctahedral micas and chlorites, but some chemical characteristics can still be discerned. XRD and AEM reveal a tendency for the micas to be more similar to muscovite and less to illite with increasing metamorphic grade, although both compositions are present in all samples. The extent of phengitic substitution is extremely low, indicating low-pressure conditions. The formation of chlorite and its composition are mainly controlled by the host-rock composition.
\end{abstract}

Keywords: low-grade metamorphism, Iberian Massif, metapelitic rocks, phyllosilicates, index of crystallinity, transmission electron microscopy, dioctahedral mica, South Portuguese Zone, Portugal.

\section{SOMMAIRE}

Les séquences métasédimentaires dévoniennes et carbonifères du secteur extrême-sud du Massif Ibérique, faisant partie de l'orogène hercynienne dans le sud-ouest du Portugal, contient des shales et des ardoises formés à un degré de métamorphisme faible mais variable. Ces roches ont été étudiées par microscopie optique et par diffraction $\mathrm{X}$ afin d'obtenir des données de base

$\S \quad$ E-mail address: miabad@ugr.es 
à propos de leur contenu en argiles et les paramètres cristallochimiques associés (IC, l'indice de "cristallinité", $b$ et $d_{001}$ ). Les techniques de microscopie électronique à balayage, microscopie électronique à haute résolution et microscopie électronique analytique ont été utilisées pour caratériser les relations texturales et l'évolution chimique des minéraux, surtout les phyllosilicates. Une bonne relation existe entre les données obtenues en diffraction $\mathrm{X}$ et celles obtenues par microscopie électronique. L'association principale de minéraux est quartz + mica dioctaédrique riche en $\mathrm{K}+$ feldspaths, mais les roches contiennent aussi un mica intermédiaire à $\mathrm{Na}-\mathrm{K}$, paragonite, kaolinite et chlorite, quoique de façon non uniforme. L'épaisseur des cristallites, mesurée directement à partir des images de franges réticulaires, est liée à l'indice de cristallinité, et fournit donc une information à propos de l'évolution du métamorphisme dans ces séquences: l'indice de cristallinité diminue du sud-ouest vers le nord-est. Les valeurs de cet indice dans les roches des formations de Brejeira et Mira correspondent à celles attendues d'un milieu de diagenèse ou de l'anchizone; dans les roches des formations Mértola et Phyllite-Quartzite, elles correspondent à l'anchizone supérieur ou à l'épizone, tandis que dans la Formation de Pulo do Lobo, elles sont typiques de l'épizone. Malgré cette disposition en zones, les changements en degré de métamorphisme ne seraient pas progressifs. Les démarcations abruptes entre les valeurs caractéristiques de chaque formation stratigraphique résulteraient de la présence de surfaces de chevauchement. Les données texturales fournissent une indication claire du degré de recristallisation, les échantillons les plus faiblement recristallisés produisant une microstructure parallèle au litage et des empilements de phyllosilicates. En revanche, les échantillons pélitiques les plus intensément recristallisés contiennent un clivage dû à un microplissement, et une matrice recristallisée. A mesure qu' augmente le degré de métamorphisme, l'épaisseur des cristaux augmente, et la densité de défauts diminue dans les phyllosilicates, quoique la chlorite possède une densité plus élevée de défauts dus à la déformation que le mica. La composition des micas dioctaédriques et de la chlorite varie grandement, mais il est encore possible d'en extraire certaines généralités. Les données obtenues par diffraction $\mathrm{X}$ et par microscopie électronique analytique montrent une tendance pour le mica dioctaédrique de ressembler davantage à la muscovite qu'à l'illite à mesure que l'intensité du métamorphisme augmente, quoique les deux compositions sont présentes dans tous les échantillons. La portée d'une substitution vers la phengite est très limitée, conforme à la faible pression de recristallisation. La formation de la chlorite et sa composition dépendent surtout de la composition de la roche-hôte.

(Traduit par la Rédaction)

Mots-clés: métamorphisme de faible intensité, Massif Ibérique, roches métapélitiques, phyllosilicates, indice de cristallinité, microscopie électronique par transmission, mica dioctaédrique, zone Portuguaise du Sud, Portugal.

\section{INTRODUCTION}

Knowledge of the physics of mineral processes in low-temperature geological environments is complicated by the small grain-size, common intergrowths of phases, structural defects and general lack of equilibrium. Consequently, in the establishment of subdivisions on the basis of grade in diagenesis, very-low-grade and low-grade metamorphism is generally precluded, or at least hindered, by the absence of the usual criteria present at higher metamorphic grades. Genetically indicative textures are only found below the optical microscopy scale, and chemically homogeneous areas are not resolved with an electron microprobe. Electron microscopy techniques are thus essential for insight into mineral processes.

We provide here results of a study of the diagenetic to very low-grade metamorphic evolution of metapelitic rocks, with a focus on the phyllosilicate phases (micas and chlorite) in rocks from the Iberian Massif in southwestern Portugal. We document their crystal-chemical parameters, compositions and textural relationships at a lattice scale.

\section{BACKGROUND INFORMATION}

During recent years an increasing number of studies have been carried out applying electron microscopy to diagenetic sequences, such as of the Gulf Coast (Ahn \& Peacor 1986), North Sea (Lindgreen \& Hansen 1991) and the Basque-Cantabrian Basin (Nieto et al. 1996), as well as to very low-grade metamorphic belts, such as the Martinsburg Formation (Lee et al. 1986), Welsh Basin (Li et al. 1994), Southern Uplands (Merriman et al. 1995), Franciscan Complex (Dalla Torre et al. 1996) and North Cornwall (Warr \& Nieto 1998). The general features of the mineral processes occurring during diagenesis and very-low-grade metamorphism are now understood (Merriman \& Peacor 1999). Mineral phases initially react and evolve metastably, such that characteristics of the original material determine the products. There is a general lack of textural and chemical equilibrium, and the exact nature of the material present in any given part of the sample is highly dependent on local factors. With increasing metamorphic grade and the consequent development of slaty cleavage, heterogeneity is progressively reduced, and the nature, texture and composition of minerals converge toward a stable state. Nevertheless, most of the details of this general process are still poorly known, in particular those regarding the compositional evolution of mineral phases.

Munhá (1983a) described the metamorphic evolution of the South Portuguese Zone of the Iberian Variscan Belt (Lotze 1945) on the basis of mineral compositions from interbedded metabasic rocks, with some data from pelitic rocks in places where no metabasic rocks exist. A progressive increase in grade of metamorphism from diagenetic conditions in the southwest to greenschist-facies conditions to the northeast was found. 
This sequence is potentially interesting for the study of mineral processes in very-low-grade metapelitic rocks: 1) it represents a general evolution from diagenesis to low-grade metamorphism over an extended, compositionally monotonous area of more than $100 \mathrm{~km} .2$ ) The presence of intercalations of basic rock allows one to determine the metamorphic grade in such low-temperature conditions. 3) The coexistence of slate and sandstone in the sequence could lead to a comparison of the metamorphic evolution in the two kinds of rocks. 4) The intrusion of the Monchique Granite in the diagenetic part of the sequence opens the possibility for a study of the effect of thermal metamorphism in a sequence relatively free of other metamorphic effects.

For this study, 76 unaltered samples of shales and slates were carefully taken in order to minimize the effects of weathering along a SW-NE cross-section (Fig. 1). The samples, representative of different metamorphic grades in the sequence, were studied by X-ray powder diffraction (hereafter XRD). On the basis of these results, four samples were selected for electron microscopy studies, including scanning electron microscopy (SEM), transmission electron microscopy (HRTEM) and analytical electron microscopy (AEM).

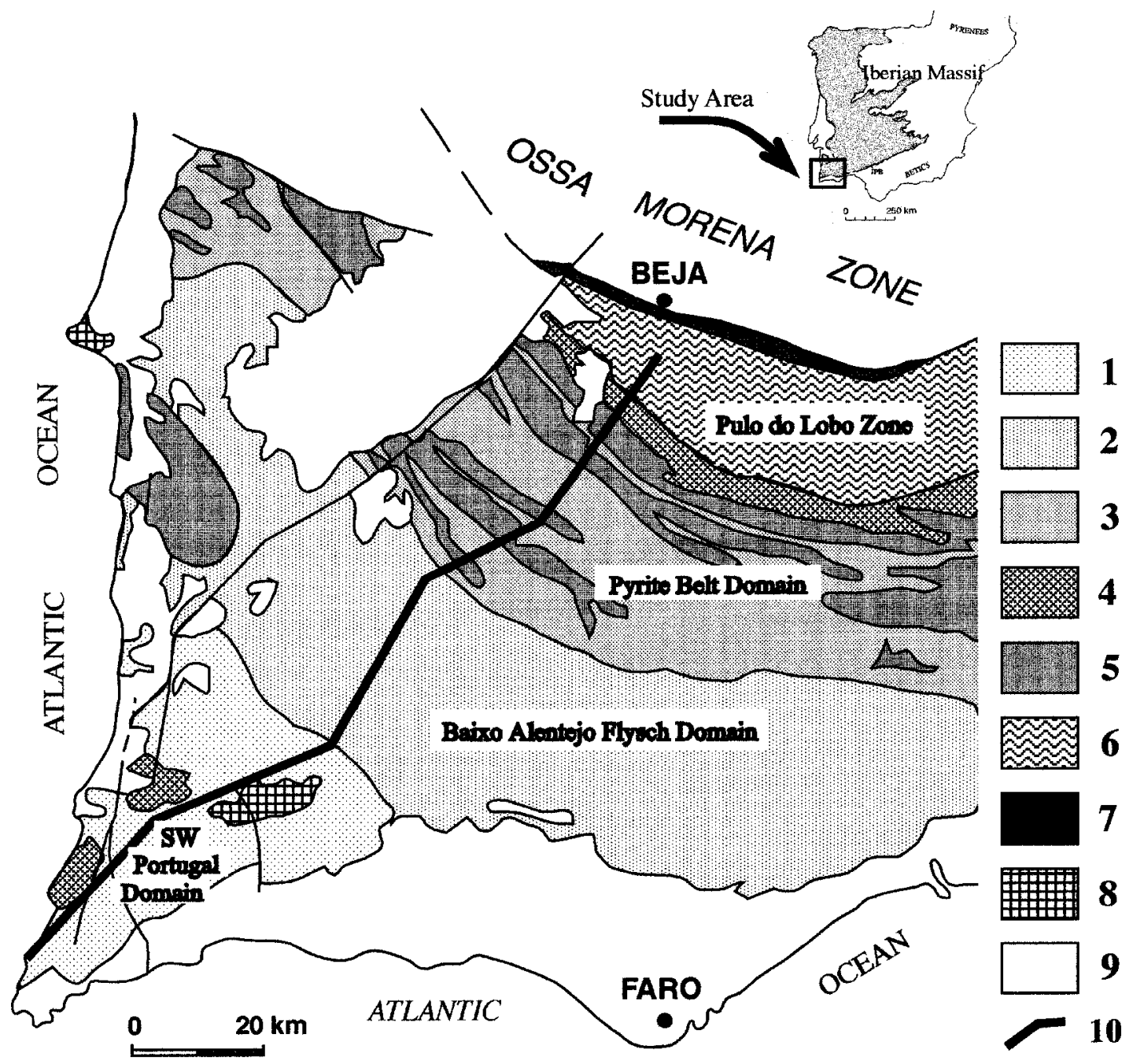

FIG. 1. Geological map of the South Portuguese Zone, adapted from Oliveira (1990) and Quesada et al. (1991). Synorogenic flysch sequences (Culm): 1) Brejeira Formation, 2) Mira Formation, 3) Mértola Formation, 4) Pre-orogenic sequences (mainly Phyllite-Quartzite Formation), 5) Volcano-Sedimentary Complex, 6) Pulo do Lobo Formation, 7) Beja-Acebuches Ophiolite, 8) Peralkaline intrusions, 9) Mesozoic-Cenozoic detritic cover, 10) Profile of sample location. 


\section{Geological Setting}

The western half of the Iberian Peninsula is occupied by the Iberian Massif, which forms part of the European Hercynian orogen (inset map in Fig. 1). The southernmost sector of the Iberian Massif, the so-called South Portuguese Zone (SPZ), consists of Upper Paleozoic sedimentary sequences with intercalations of felsic and basic volcanic rocks. This zone has been interpreted as an exotic terrane that collided with the Ossa-Morena Zone (sector of the Iberian autochthon) during the Hercynian orogeny (Munhá et al. 1986, Quesada 1991, 1998, Quesada et al. 1994). The boundary between the two zones is a typical suture-zone and is exposed along the entire length of a belt of Paleozoic oceanic rocks of the Pulo do Lobo Zone and the Beja-Acebuches Ophiolite Complex (Quesada et al. 1994) (Fig. 1).

The oldest metasedimentary rocks studied here belong to the Pulo do Lobo Formation, dated as Lower Devonian by Oliveira (1990). This formation is composed of sheared phyllites and quartzites. Minor interbedded felsic volcanic rocks, at the top, and metabasalts toward the base, have been identified. On the basis of structural characteristics and the geochemical signature of the mafic rocks, this formation has been considered as part of an accretionary prism resulting from the Hercynian collision (Quesada 1991, Quesada et al. 1994).

The South Portuguese Zone includes late Paleozoic sequences comprising, from bottom to top: 1) The Phyllite-Quartzite Formation: a platformal detrital formation (Schermerhorn 1971) made up of alternations of phyllites and quartzites, some conglomerates and lenses of limestone. The age of this pre-orogenic formation is Famennian (Oliveira 1990). 2) The VolcanoSedimentary Complex (VSC) is a heterogeneous sequence of felsic to mafic volcanic rocks, shale, sandstone, jasper, and manganese ore; it hosts massive sulfide deposits [see Leistel et al. (1998) for a review]. This complex has been dated as Upper Famenian to Middle Visean and indicates bimodal volcanic activity (Schermerhorn 1971, Munhá 1983b). Sequences 1) and 2) are the main constituents of the Iberian Pyrite Belt. 3) The Baixo Alentejo Flysch Group (Oliveira et al. 1979) is composed of synorogenic sequences (Culm facies) of gravity-flow sediments that form a southward prograding detrital cover. Three main basin formations are distinguished (Oliveira et al. 1979, Oliveira 1990): the northernmost, the Mertola Formation, has been dated as Upper Visean and comprises sequences of feldspathic greywackes and shales with high sandstone:shale ratio. The Mira Formation is composed of several centimeter-thick beds of turbidites with a low sandstone:shale ratio. This formation is Late Visean to early Late Namurian in age. Finally, the Brejeira Formation, cropping out in the southwestern Portugal domain, is a turbiditic sequence of heterogeneous lithology, mainly comprising dark quartzitic sandstones and shales. The shales are decimeters thick, grayish to bluish, and contain plant debris. Goniatites indicate a Middle Namurian to Lower Westphalian age for this formation (Oliveira et al. 1979).

\section{Metamorphism and deformation}

During the Hercynian Orogeny, the SPZ was deformed by the development of cleavage and regional metamorphism. The most notable structural feature of this zone is the formation of an imbricate stack of thin, folded thrust-sheets during a major phase of transpressional deformation related to obduction of the OssaMorena Zone onto the SPZ (Quesada 1998).

The deformation and metamorphism in the southern part of the Iberian Massif have different characteristics in each structural domain. In the Pulo do Lobo Formation, three stages of deformation have been distinguished. The second produced the dominant cleavage, and the third, a weak crenulation (Silva et al. 1990, Quesada et al. 1994). The main metamorphic recrystallization coincided with the second stage, where the major event of deformation due to the collision resulted in greenschist-facies conditions (Munhá 1990).

In the Iberian Pyrite Belt, the rocks of the VolcanoSedimentary Complex underwent early hydrothermal metamorphism contemporaneous with volcanic activity. Important chemical changes in the rocks took place, and led to the formation of chlorite and white mica (Munhá \& Kerrich 1980, Munhá 1990, Leistel et al. 1998). The metamorphic grade ranges from the zeolite to the greenschist facies.

Two predominant cleavages are related to the Hercynian deformation (Silva et al. 1990, Quesada 1998): local mylonitic foliation associated with shear zones and widespread slaty cleavage related to folding, which becomes less penetrative toward the south. The metamorphic blastesis took place mainly during the second stage.

Munhá (1983a) defined four metamorphic zones; grade increases from Zone 1 in zeolite facies in the southern region, through prehnite-pumpellyite to greenschist facies in Zones 2 and 3, developed in the Pyrite Belt, to zone 4, corresponding to greenschist facies in the Pulo do Lobo Formation in the north.

\section{Methods of AnAlysis}

\section{$X$-ray diffraction}

After washing and coarse crushing, homogeneous chips of rocks were selected for the X-ray-diffraction analyses, carried out using a Philips PW 1710 powder diffractometer with $\mathrm{Cu} K \alpha$ radiation, graphite monochromator and automatic divergence slit. The $<2 \mu \mathrm{m}$ fraction was separated by centrifugation through a column of water, on the basis of Stokes's law. Oriented aggregates were prepared by sedimentation on glass slides. 
Ethylene glycol, dimethyl sulfoxide and heat treatments were carried out on some of samples to corroborate the identification of kaolinite, corrensite and smectite on the basis of the expandability of these phases. Preparation of samples and experimental conditions for measurements of illite "crystallinity" (IC) were carried out according to IGCP 294 IC Working Group recommendations (Kisch 1991). Our IC measurements $(y)$ were transformed into crystallinity index standard (CIS) values $(x)$ according to the equation $y=0.674 x+0.052$ $(r=0.999)$, obtained in our laboratory using the international standards of Warr \& Rice (1994). The $b$ parameter of mica and chlorite were obtained from the (060) peak measured on slices of rock cut normal to the sample foliation (Sassi \& Scolari 1974). Such slices are essentially perpendicular to the (001) planes of phyllosilicates and thus avoid interference from peaks other than (060) (Frey 1987). For all the measurements of spacings, quartz from the sample itself was used as internal standard.

\section{Chemical analyses}

Whole-rock analyses were carried out using X-ray fluorescence, neutron activation, inductively coupled plasma and atomic absorption spectrometry at the XRay Assay Laboratories in Lancaster, Ontario, Canada.

\section{Scanning electron microscopy and transmission electron microscopy}

Four samples were selected as representative, on the basis of the IC values, differences in the mineral assemblages and their tectonostratigraphic position, for a study by electron microscopy techniques. SEM observations of these four samples made use of back-scattered electron (BSE) imaging, performed on both polished thin sections and ion-milled specimens using a Hitachi S$3200 \mathrm{~N}$ SEM, operated at $20 \mathrm{kV}$ and equipped with a Noran X-ray energy-dispersion system (EDS) (University of Michigan). Following optical and BSE examination, specimens were removed from thin sections, ion-milled and carbon-coated. TEM observations were obtained with two different microscopes: 1) a Philips CM12 scanning transmission electron microscope (STEM) operated at an accelerating voltage of $120 \mathrm{kV}$ and beam current of $\sim 10 \mu \mathrm{A}$ equipped with a Kevex Quantum EDS system (University of Michigan), and 2) a Philips CM20 (STEM) equipped with an EDAX solidstate EDX detector, operating at $200 \mathrm{kV}$, with $\mathrm{a} \mathrm{LaB}_{6}$ filament (Centro de Instrumentación Científica, Universidad de Granada). Lattice-fringe images of phyllosilicates were obtained using $00 l$ reflections. TEM images were generally obtained at $100,000 \times$ magnification.

X-ray energy-dispersion spectra of ion-milled samples were obtained using a Kevex Quantum detector and a raster of $1000 \times 200 \AA$ in scanning mode, with the long axis oriented parallel to the phyllosilicate packets to minimize alkali volatilization. AEM quantitative chemical analyses were calculated from spectra using ion-milled standards of muscovite, albite, clinochlore, fayalite and titanite to derive K-ratios, following the procedure of Jiang et al. (1990).

AEM data were also obtained from powdered portions prepared using holey $\mathrm{C}$-coated formvar $\mathrm{Cu}$ grids. This preparation disperses individual grains of minerals onto the grid surface. The monomineralic character of each grain was checked by its electron-diffraction pattern. The analyses performed on particles, on holey Ccoated formvar $\mathrm{Cu}$ grids, pertain to a larger area $(1 \times 1$ $\mu \mathrm{m})$ and produce better reproducibility of data owing to the decrease in the loss of alkalis. Shorter counting times (30 s) were used as a compromise in analyses for K (Nieto et al. 1996). Albite, biotite, spessartine, muscovite, olivine, titanite, $\mathrm{MnS}$ and $\mathrm{CaS}$ were used as standards to derive $\mathrm{K}$-factors for the transformation of intensity ratios to concentration ratios following the procedures of Cliff \& Lorimer (1975).

Structural formulae of micas were calculated on the basis of 22 negative charges, $\mathrm{O}_{10}(\mathrm{OH})_{2}$. The terms muscovite, illitic and phengitic are used according to the IMA nomenclature for micas (Rieder et al. 1998).

\section{RESULTS}

\section{$X$-ray diffraction}

The bulk mineralogy, determined by XRD, mainly comprises quartz, feldspars, phyllosilicates (micas and chlorite) and oxides (Table 1). Quartz, dioctahedral micas and feldspars (K-feldspar except for the deepest samples, in which albite takes its place) occur in all the samples. Dioctahedral micas are the main constituent of the $<2 \mu \mathrm{m}$ fraction. $\mathrm{Na}-\mathrm{K}$ intermediate mica is present in Brejeira and Mira formations; it can be recognized by a rational series of $(00 l)$ peaks corresponding to $9.98 \AA$ spacing, which is intermediate between the spacings of muscovite and paragonite (Frey 1987). Paragonite is found also in the Mira Formation. Significant amounts of kaolinite, smectite and corrensitic minerals have been detected in some samples at various depths of the sequence (Fig. 2). Accessory minerals include iron oxides and hydroxides.

The basal spacing $\left(d_{001}\right)$ of dioctahedral mica is close to $10.00 \AA$, with a standard deviation of $0.01 \AA$ (Table 1). This average value drops to $9.99 \AA$ for the Pulo do Lobo Formation. An overall average value of $8.988 \AA(\sigma 0.006)$ is obtained for the $b$ parameter XRD data. The $b$ unit-cell parameter is slightly greater in the deeper formations. This low value, together with the $d_{001}$, seems to indicate a composition near muscovite for the micas, with a very low phengitic component. In terms of the diagram of Guidotti et al. (1992), samples plot very near the line corresponding to no phengitic component and $\mathrm{Na} /(\mathrm{Na}+\mathrm{K})$ approximately equal to 0.1 . 
TABLE 1. CRYSTAL-CHEMICAL PARAMETERS AND BULK MINERALOGY OF DIAGENETIC-METAMORPHIC ROCKS OF THE SOUTH PORTUGUESE ZONE, AS DETERMINED BY X-RAY DIFFRACTION

\begin{tabular}{|c|c|c|c|c|c|}
\hline \multicolumn{3}{|c|}{ White mica } & \multicolumn{2}{|l|}{ Chlorite } & \multirow{3}{*}{$\begin{array}{c}\text { Mineralogy } \\
\text { Ms, Qtz, Feldspars } \\
\text { (all the samples) }\end{array}$} \\
\hline$d(002)$ & & $\mathrm{IC}<2 \mu \mathrm{m}$ & $d(001)$ & & \\
\hline$<2 \mu \mathrm{m} \quad$ bulk & $b$ & $10 \AA 5 \AA$ & $<2 \mu \mathrm{m}$ bulk & $b$ & \\
\hline
\end{tabular}

Data for rocks of the Brejeira Formation

\begin{tabular}{|c|c|c|c|c|c|c|c|c|c|}
\hline Pa-1 & 10.011 & 10.002 & 8.980 & 0.35 & 0.41 & & 14.11 & 9.260 & $\mathrm{Kln}, \mathrm{Chl}$ \\
\hline $\mathrm{Pa}-2$ & 9.995 & 9.992 & 8.990 & 0.37 & 0.37 & & & 9.254 & $\mathrm{Kln}, \mathrm{Chl}$ \\
\hline $\mathrm{Pa}-3$ & 10.008 & 9.986 & 8.984 & 0.46 & 0.40 & & 14.12 & & $\mathrm{Kin}, \mathrm{Ill} / \mathrm{Pg}, \mathrm{Gt}, \mathrm{Ch}$ \\
\hline $\mathrm{Pb}-4$ & 10.014 & 10.019 & & 0.49 & 0.46 & 14.13 & 14.12 & & Ill/Pg, Gt, Chl \\
\hline $\mathrm{Pb}-5$ & 10.006 & 10,009 & 8.984 & 0.50 & 0.56 & 14,13 & 14.13 & 9.291 & Ill/Pg, Hem, $\mathrm{Chl}$ \\
\hline $\mathrm{Pb}-6$ & 10.011 & 10,006 & 8.984 & 0.46 & 0.50 & 14.12 & 14.12 & 9.303 & $\mathrm{Ill} / \mathrm{Pg}, \mathrm{Chl}$ \\
\hline $\mathrm{Pb}-7$ & 10.002 & 10.003 & 8.990 & 0.53 & 0.55 & 14.12 & 14.13 & & Ill/ $/ \mathrm{Pg}$, Chl, Tur \\
\hline $\mathrm{Pc}-8$ & 9.993 & 9.992 & 8.982 & 0.47 & 0.59 & & & & $\mathrm{Ill} / \mathrm{Pg}, \mathrm{Kln}, \mathrm{Gt}$ \\
\hline Pc-9 & 10.009 & 9.997 & 8.981 & 0.43 & 0.34 & & & & Ill/Pg, Kln \\
\hline Pc-10 & 10.007 & 9.992 & 8.982 & 0.46 & 0.44 & & & & Ill/Pg, Kin \\
\hline $\mathrm{Pd}-12$ & 9.992 & 9.993 & 8.987 & 0.43 & 0.53 & & 14,13 & 9.303 & $\mathrm{Ill} / \mathrm{Pg}, \mathrm{Chl}$ \\
\hline $\mathrm{Pd}-14$ & 9.999 & 9.988 & 8.984 & 0.41 & 0.41 & & & & Ill/Pg, Kln \\
\hline Pd-15 & 10.003 & 9.992 & 8.986 & 0.46 & 0.49 & & & & $\mathrm{Ill} / \mathrm{Pg}, \mathrm{K} \ln$ \\
\hline Pe-16 & 10.001 & 10.004 & 8.977 & 0.38 & 0.37 & 14.10 & 14.13 & 9.306 & Ill/Pg, Chl \\
\hline Pe-17 & 10.002 & 10.002 & 8.981 & 0.40 & 0.38 & 14.11 & 14.12 & 9.275 & $\mathrm{Il1} / \mathrm{Pg}, \mathrm{Chl}$ \\
\hline Pe-18 & 10.002 & 10.004 & 8.990 & 0.37 & 0.34 & & & & Kln \\
\hline Pe-19 & 10.004 & 10.005 & 8.986 & 0.41 & 0.41 & & & & Ill/Pg, Kin \\
\hline $\mathrm{Pf}-20$ & 10.014 & 10.008 & 9.986 & 0.40 & & & & & Ill/Pg, Kln \\
\hline Pf-21 & 10.013 & 10.004 & 8.985 & 0.40 & 0.38 & & & & Ill/Pg, Kln \\
\hline Pf-22 & 10.012 & 10.003 & 8.988 & 0.32 & 0,32 & & & & Ill/Pg, Kln \\
\hline Pg-25 & 9.993 & 9.993 & & 0.41 & & & & & $K \ln$ \\
\hline $\mathrm{Pg}-26$ & 10.006 & 10.006 & 8.987 & 0.31 & 0.28 & & & & Kln, Ill/Pg \\
\hline $\mathrm{Pg}-27$ & 9.984 & 10.005 & 8.989 & 0.28 & 0.29 & & & & Kln, $\mathbf{P g}$ \\
\hline $\mathrm{Ph}-28$ & 10.007 & 9.997 & 8.984 & 0.38 & 0.35 & & & & $\mathrm{Kln}, \mathrm{Ill} / \mathrm{Pg}$ \\
\hline Ph-29 & 10.004 & 9.991 & 8.978 & 0.41 & 0.44 & & & & $\mathrm{~K} \ln , \mathrm{Ill} / \mathrm{Pg}$ \\
\hline Ph-30 & 10.002 & 9.990 & & 0.41 & 0.41 & & & & $\mathrm{Kln}, \mathrm{W} / \mathrm{Pg}, \mathrm{Pg}$ \\
\hline $\mathrm{Ph}-31$ & 10.003 & 9.992 & 8.986 & 0.50 & 0.49 & & & & $\mathrm{~K} \ln , \mathrm{Il} / \mathrm{Pg}$ \\
\hline
\end{tabular}

Data for rocks of the Mira Formation

$\begin{array}{llllllll}\text { Pi-32 } & 10.016 & 9.987 & 8.982 & 0.49 & 0.50 & 14.16 & 14.13\end{array}$ $\begin{array}{lllllllll}\text { Pi-34 } & 9.956 & 9.980 & 8.983 & 0.44 & 0.46 & 14.18 & 14.14\end{array}$

$\begin{array}{lllll}\mathrm{Pi}-35 & 9.994 & 8.993 & 0.49 & 0.53\end{array}$

$\begin{array}{llllll}\text { Pj-36 } & 9.987 & 9.988 & 8.987 & 0.41 & 0.46\end{array}$

$\begin{array}{llllllll}\text { Pj-37 } & 10.014 & 10.016 & 0.41 & 0.64 & 14.14 & 14.14\end{array}$

$\begin{array}{lllllll}\text { Pk-40 } & 9.994 & 10.002 & 8.986 & 0.52 & 0.47 & \text { Ill/Pg, Kln, Gt }\end{array}$

$\begin{array}{llllllll}\mathrm{Pk}-41 & 9.993 & 9.996 & 0.44 & 0.44 & 14.12 & 14.13 & \text { Ill/Pg, Chl }\end{array}$

$\begin{array}{llllllllll}\text { Pk-43 } & 10.004 & 10.000 & 8.985 & 0.50 & 0.47 & 14.14 & 14.14 & 9.291 & \mathrm{Il} / \mathrm{Pg}, \mathrm{Pg}, \mathrm{Chl}\end{array}$

$\begin{array}{llllllllll}\mathrm{P} l-44 & 10.004 & 10.008 & 8.980 & 0.49 & 0.41 & 14.16 & 14.15 & \mathrm{IIl} / \mathrm{Pg}, \mathrm{Ch}\end{array}$

$\begin{array}{lllllll}\mathrm{Pl}-46 & 9.995 & 9.986 & 0.44 & 0.40 & \text { Ill/Pg, Pg, Kln, Gt }\end{array}$

$\begin{array}{llllllllll}\mathrm{Pl}-47 & 9.994 & 10.001 & 8.988 & 0.46 & 0.44 & 14.14 & 14.12 & 9.291 & \text { Ill/Pg, Pg, Kln, Gt, }\end{array}$

$\mathrm{Chl}$

$\begin{array}{lllllll}\text { Pm-48 } 10.007 & 9.996 & 0.47 & 0.47 & 14.13 & 14.13 & \text { Ill/Pg } / \mathrm{Kln}, \mathrm{Ch}, \mathrm{Gt}\end{array}$

$\begin{array}{llllllll}\text { Pm-49 } 10.005 & 9.994 & 8.989 & 0.47 & 0.47 & 14.16 & 9.284 & \text { IllPg, Chl, Gt }\end{array}$

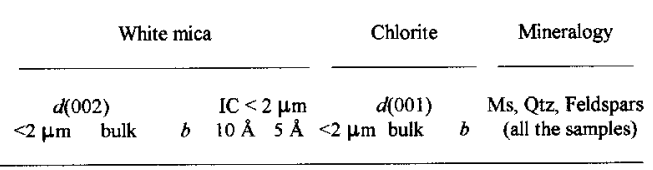

Data from rocks of the Mira Formation (continued)

$\begin{array}{llllllllll}\text { Pm-51 } & 9.992 & 10.006 & 8.991 & 0.49 & 0.41 & 14.13 & 14.13 & 9.299 & \text { Ill/Pg, Chl }\end{array}$

$\begin{array}{llllllll}\mathrm{Pn}-52 & 10.013 & 10.004 & 8.989 & 0.55 & 0.47 & 14.13 & \mathrm{Pg}, \mathrm{Ill} / \mathrm{Pg} \mathrm{Kln}, \mathrm{Chl}\end{array}$

$\begin{array}{lllllll}\text { Pnl-54 } & 10.005 & 9.997 & 8.984 & 0.55 & \mathbf{0} & \end{array}$

$\begin{array}{llllllllll}\text { Pn-55 } & 10.005 & 10.008 & 8.990 & 0.47 & 0.47 & 14.13 & 14.14 & 9.299 & \mathrm{Ill} / \mathrm{Pg}, \mathrm{Pg}, \mathrm{Chl}\end{array}$

$\begin{array}{llllllll}\text { Po-56 } 10.001 & 8.991 & 0.34 & 0.34 & 14.14 & C h l\end{array}$

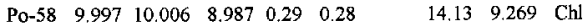

$\begin{array}{lllllll}\text { Po-59 } & 10.003 & 10.003 & 8.990 & 0.32 & 0.32 & \mathrm{Ch}, \mathrm{Chl} / \mathrm{Crr}\end{array}$

\section{Data for rocks of the Mértola Formation}

$\begin{array}{llllll}\text { Pp-60 } & 10.003 & 9.997 & 8.993 & 0.19 & 0.22\end{array}$

$\begin{array}{llllll}\text { Pp-61 } & 10.004 & 10.001 & 8.991 & 0.29 & 0.20\end{array}$

$\begin{array}{llllllll}\text { Pp-62 } & 10.002 & 10.002 & 8.994 & 0.23 & 0.26 & 14.12 & 14.15\end{array}$

$\begin{array}{lllllllllll}\text { Pp-63 } & 10.003 & 10.002 & 8.992 & 0.25 & 0.22 & 14.15 & 14.14 & 9.288\end{array}$

$\begin{array}{lllllll}\text { Pq-65 } & 9.995 & 9.997 & \mathbf{8 . 9 9 6} & 0.26 & 0.25\end{array}$

$\begin{array}{lllll}\mathrm{Pq}-66 & 9.999 & 10.003 & 0.26 & 0.25\end{array}$

$\begin{array}{lllll}\text { Ps-71 } 9.996 & 0.28 & 0.25 & 14.13\end{array}$

$\begin{array}{llllllllll}\text { Ps-72 } & 9.991 & 9.995 & 8.993 & 0.26 & 0.26 & 14.13 & 14.14 & 9.284 & \mathrm{Chl}, \mathrm{Gt}\end{array}$

$\begin{array}{llllllllll}\mathrm{Pu}-76 & 10.002 & 9.999 & 8.989 & 0.18 & 0.18 & 14.16 & 14.16 & 9.277 & \mathrm{Chl}\end{array}$

$\begin{array}{lllllllllll}\mathrm{Pu}-77 & 9.997 & 9.996 & 9.000 & 0.19 & 0.18 & 14.16 & 14.14 & 9.288 & \mathrm{Sm}, \mathrm{Chl}\end{array}$

$\begin{array}{llllllllll}\text { Pu-78 } & 9.999 & 10.005 & 8.990 & 0.22 & 0.19 & 14.13 & 14.14 & 9.288 & \mathrm{Chl}\end{array}$

\section{Data for rocks of the Phyllite-Quarzite Formation}

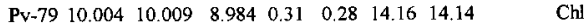
$\begin{array}{llllllllll}\text { Pw-80 } & 9.992 & 10.004 & 8.999 & 0.32 & 0.31 & 14.14 & 14.14 & 9.299 & \text { Chl }\end{array}$ $\begin{array}{llllllllll}\text { Pw-81 } & 10.010 & 10.003 & 8.981 & 0.32 & 0.32 & 14.14 & 14.14 & 9.303 & \mathrm{Chl}, \mathrm{Ill} / \mathrm{Pg}\end{array}$ $\begin{array}{llllll}\text { Pw-82 } 10.003 & 0.28 & 0.26 & 14.13 & \mathrm{Chl}, \mathrm{Il} / \mathrm{Pg}\end{array}$ $\begin{array}{llllllll}\text { Pw-82 } & 10.003 & & 0.28 & 0.26 & 14.13 & & \mathrm{Chl}, \mathrm{Il} / \mathrm{Pg} \\ \mathrm{Px}-83 & 9.988 & 10.006 & 0.18 & 0.23 & 14.16 & \mathrm{Ch}, \mathrm{Chl} / \mathrm{Crr}, \mathrm{Kln}\end{array}$ $\begin{array}{lllll}\mathrm{Px}-84 & 9.990 & 0.34 & 0.35 & \mathrm{Cl} / \mathrm{Pg}, \mathrm{Ch} \text {, }\end{array}$ $\mathrm{Chl} / \mathrm{Cr}, \mathrm{Kln}$

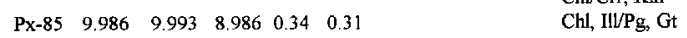

Data for rocks of the Pulo do Lobo Formation

\begin{tabular}{|c|c|c|c|c|c|c|}
\hline Pz-88 & 9.989 & & & 0.18 & 0.20 & $\mathrm{Kln}, \mathrm{Sm}, \mathrm{Chl}, \mathrm{Gt}$ \\
\hline $\mathrm{Pz}-89$ & 9.985 & 9.990 & & 0.19 & 0.20 & $\mathrm{Kln}, \mathrm{Sm}, \mathrm{Chl}, \mathrm{Gt}$ \\
\hline Pz-90 & 9.992 & 9.988 & 9.005 & 0.18 & 0.23 & $\mathrm{Sm}, \mathrm{Kln}$ \\
\hline$P \beta-92$ & 10.002 & 10.004 & & 0.23 & 0.22 & $\mathrm{Sm}, \mathrm{Kln}, \mathrm{Chl}, \mathrm{Gt}$ \\
\hline$P \beta-93$ & 9.989 & 9.982 & & 0.25 & $\begin{array}{llll}0.23 & 14.12 & 14.13\end{array}$ & $\mathrm{Sm}, \mathrm{Gt}$ \\
\hline$P \beta-94$ & 9.993 & 9.994 & & 0.22 & & $\mathrm{Sm}, \mathrm{Chl}, \mathrm{Gt}, \mathrm{Pl}$ \\
\hline PX-94 & 9.987 & 9.987 & 8.997 & 0.26 & 0.22 & Sm, Chl, Pl \\
\hline $\mathrm{PX}-95$ & 9.996 & 9.987 & 9.003 & 0.23 & 0.23 & Sm, Chl, Pl \\
\hline Pסि-96 & 9.989 & 9.992 & 8.989 & 0.26 & 0.25 & $\mathrm{Sm}, \mathrm{K} \ln , \mathrm{Pl}$ \\
\hline Pס-97 & 9.987 & 9.991 & 8.991 & 0.25 & 0.23 & $\begin{array}{l}\mathrm{Kln}, \mathrm{Chl}, \mathrm{Sm}, \mathrm{Pl}, \\
\mathrm{Gt}, \mathrm{Kfs}\end{array}$ \\
\hline
\end{tabular}

Mineral abbreviations according to Kretz (1983): Ap apatite, Chl chlorite, Gt goethite, Hem hematite, Kfs K-feldspar, Kln kaolinite, Ms muscovite, Pl plagioclase, Qtz quartz, Tur tourmaline, Vrm vermiculite. In addition, Crr corrensite, Sm smectite, Jrs jarosite, Ill/Pg $\mathrm{Na}-\mathrm{K}$ intermediate mica.

Figure 2 shows the decrease in IC from southwest to northeast. The IC values for both the Brejeira and Mira formations correspond to diagenesis and anchizone, the Mértola and Phyllite-Quartzite formations correspond to high anchizone-epizone, and the Pulo do Lobo Formation presents values typical of epizonal conditions. Nevertheless, this decrease is not invariably constant and gradual, as there are some abrupt changes. For the total oriented aggregates, the IC values of bulk samples are generally lower, that is, the material is more perfectly crystalline, than for those of the $<2 \mu \mathrm{m}$ separates, illustrating the effect of detrital micas.

The intensity ratios of basal peaks of micas obtained from the XRD diagrams describe the same ranges of values for bulk and $<2 \mu \mathrm{m}$ samples. These are represented in the Rey \& Kübler triangle (1983) (Fig. 3), which relates basal intensity ratios of micas with their chemical composition. A general tendency of the 
Mértola and Pulo do Lobo samples toward compositions closer to muscovite can be seen.

\section{Whole-rock compositions}

Selected results of chemical analyses of pelitic rocks from the various formations are given in Table 2. Major-element data show average values similar to the upper continental crust and the average of post-Archean Australian shales (PAAS) (Taylor \& McLennan 1985). Average $\mathrm{Na}$ and $\mathrm{Ca}$ values are slightly lower than in PAAS, and the $\mathrm{K}$ values are similar to those for PAAS. Low values of $\mathrm{Mg}$ have been found for all the formations, except for the Mértola Formation. The lowest $\mathrm{MgO}+\mathrm{FeO}+\mathrm{Fe}_{2} \mathrm{O}_{3}$ contents correspond to the Brejeira Formation (top of the sequence). In spite of these slight differences, these samples are representative of the average pelitic rock.

\section{SEM data}

BSE images show the texture of both detrital grains and matrix. Lower-grade samples, $\mathrm{Pc}-9$ and $\mathrm{Pk}-43$, are made up of a coarse fraction, assumed to be detrital in origin, of quartz, feldspars and phyllosilicates, and a fine-grained matrix generally lacking in resolution under the SEM. Stacks of kaolinite and mica and of chlorite and mica occur as coarse grains as well (Fig. 4A). In both samples, a bedding-parallel microfabric can be observed, with all the platy minerals also oriented parallel to the microfabric. Iron oxides and pyrite also are present as minor phases and titanium oxides are pervasive within or surrounding stacks of chlorite + mica and kaolinite + mica. Samples $\mathrm{Pw}-81$ and $\mathrm{P} \beta-94$ (anchizone and epizone) show a crenulated to cleaved microfabric (Fig. 4B). In Pw-81, the phyllosilicates are microfolded, rotated and show a marked crenulation. The chlorite-

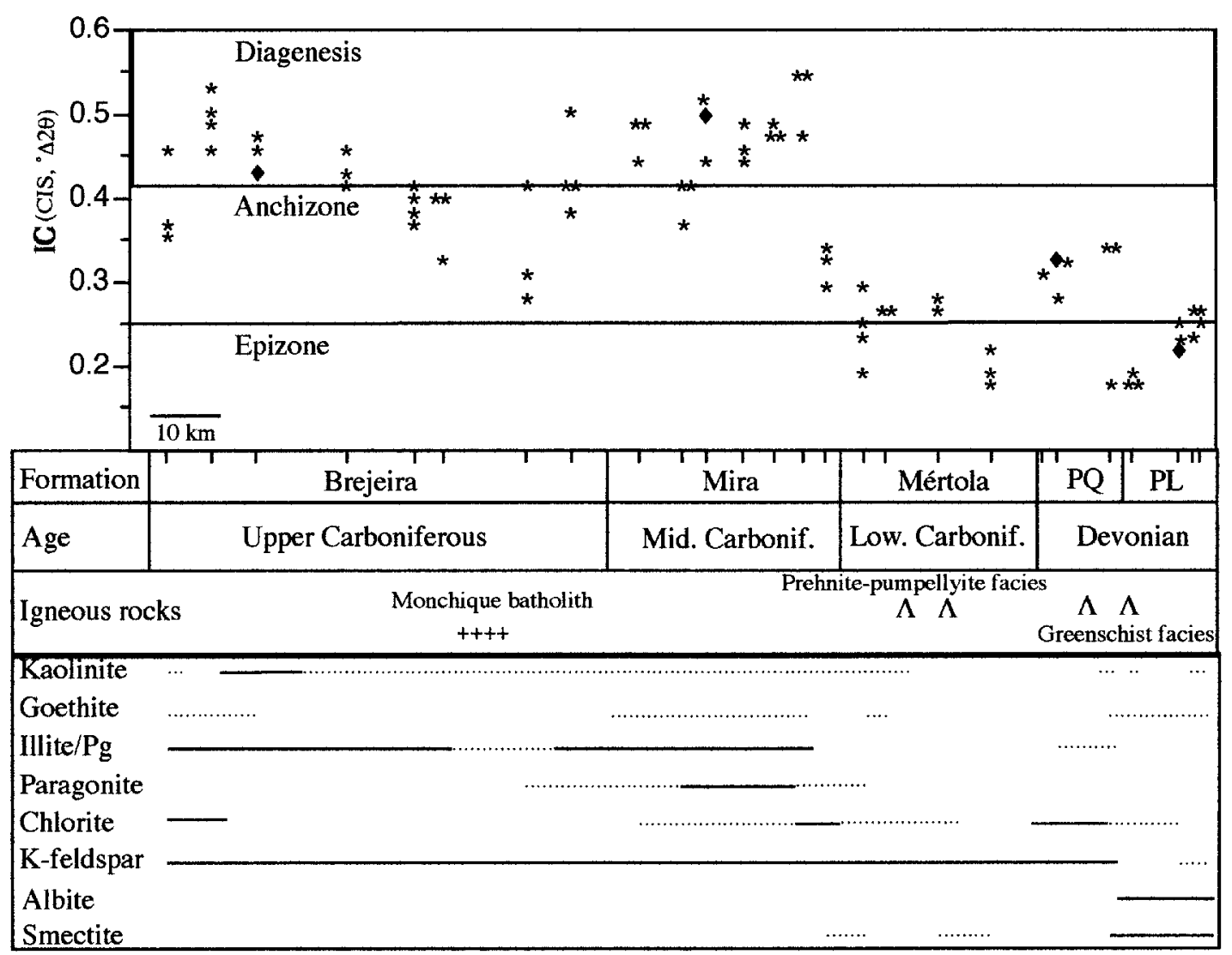

FIG. 2. Mineral composition, determined by X-ray diffraction, and illite crystallinity of the samples studied, in relation to their geological context and sample locations. All the samples contain quartz and dioctahedral mica in addition to the minerals represented. The left of the figure corresponds to the southwest (S. Vicente Cape), and the right, to the northeast (Beja). PQ Phillite-Quarzite Formation, PL Pulo do Lobo Formation. $\wedge$ : interbedded basic rocks. Diamonds indicate samples studied by SEM and TEM. 


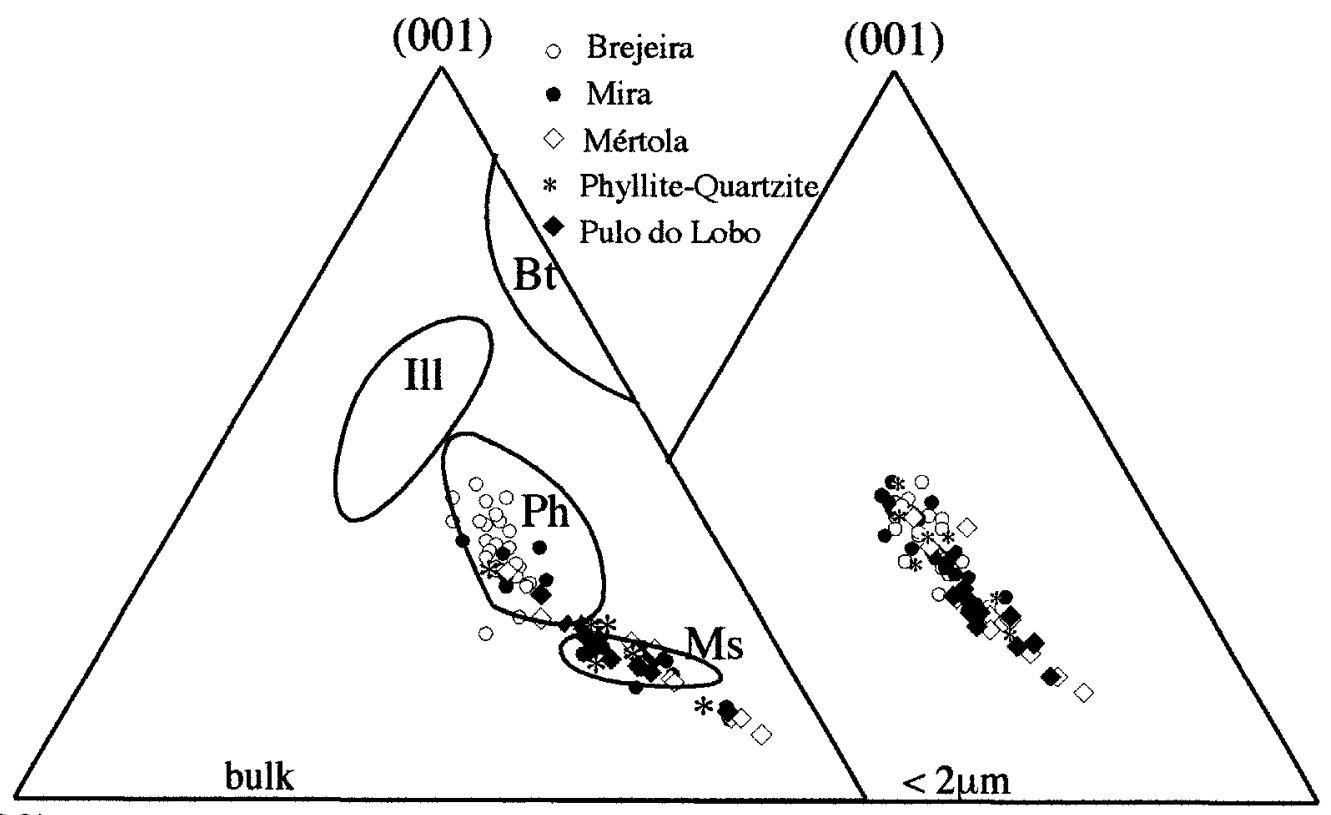

(002)

FIG. 3. Rey \& Kübler (1983) triangular plots, transformed for automatic divergence slit, of the bulk and $<2 \mu \mathrm{m}$ fraction of the studied samples. (001), (002) and (005) correspond to basal reflection intensities of dioctahedral mica. Ms: muscovite field, $\mathrm{Ph}$ : phengite field, Ill: illite field, Bt: biotite field.

mica stacks in this sample are less abundant than in Pk43. Sample $P \beta-94$ shows a crenulation-cleavage microfabric with a highly recrystallized matrix.

\section{TEM data}

TEM data reveal that dioctahedral mica is the main phyllosilicate of this sequence. At the TEM scale, samples $\mathrm{Pc}-9$ and $\mathrm{Pk}-43$ show similar characteristics, and dioctahedral mica occurs as packets less than 800 $\AA$ thick, with layer terminations, low-angle boundaries and dislocations. Packets of mica, with similar contents of $\mathrm{Na}$ and $\mathrm{K}$, intergrown with $\mathrm{K}$-dominant illite are present in both samples, and display lenticular pores (Fig. 5). In sample Pc-9, kaolinite crystals, occurring as packets of layers up to $300 \AA$ thick, are in parallel intergrowth with thick packets of mica. Sample $\mathrm{Pk}-43$ has abundant illite-chlorite intergrowths up to several hundreds Å thick (Fig. 6). Electron-diffraction patterns show a dominant $2 M$ polytype for dioctahedral mica. Layer terminations and low-angle contacts are less abundant than in sample Pc-9.

As metamorphic grade increases, the thickness of dioctahedral mica crystals also increases, and defects such as dislocations and layer terminations decrease. Nonetheless, deformation-induced features, such as kink bands, higher-angle contacts between thick packets and fractured crystals, can be observed in sample Pw-81. Chlorite and dioctahedral mica show differences in their microtextures, with chlorite having a higher density of strain-related defects (e.g., kinks) than mica. Figure 7A illustrates the features typical of variable contact-angle between kinked chlorite and thick, parallel crystals of muscovite.

Sample P $\beta-94$ displays thick crystallites (Fig. 7B). Muscovite packets on the order of more than $1000 \AA$ thick have a mottled texture and sharp $2 M$-layer electron-diffraction patterns. The low density of defects is probably the result of a complete pressure-solution recrystallization that obliterated the previous texture.

Although a prograde sequence can be defined, diagenetic minerals have also been detected in epizonal samples. The most characteristic feature is the presence of discrete packets of corrensite and of smectite parallel to $2 M$ muscovite in the Pulo do Lobo sample ( $\mathrm{P} \beta-94)$. The alternation of 10-14 $\AA$ layers and results of AEM analyses of these zones confirm the presence of corrensite. TEM images show muscovite altering to smectite, and chlorite altering to corrensite layers. Thin packets of kaolinite (up to $50 \AA$ thick) have been identified as well.

Figure 8 shows histograms of illite crystallite-thickness measured in the direction parallel to $c^{*}$ in TEM lattice-fringe images. All the samples show thickness 
distributions characterized by positive skewness, with the median and the modes being smaller than the mean values. With increasing grade, thickness distributions are more irregular and broader, showing scattered values in the highest-grade sample $(\mathrm{P} \beta-94)$.

\section{AEM data on micas}

The chemical formulae of dioctahedral micas are presented in Table 3. The data are widely scattered within each sample and among different samples. This scatter is greater in $\mathrm{Pc}-9$ and $\mathrm{Pk}-43$ than in $\mathrm{Pw}-81$ and $\mathrm{P} \beta-94$, and more evident in the $\mathrm{Si} / \mathrm{Al}$ ratio and interlayer populations.

The effect of detrital micas on these chemical differences is difficult to evaluate owing to a lack of obvious textural characteristics indicative of a detrital origin. Occasionally, a perfect crystalline character, absence of defects, irregular shapes and an anomalously large grain-size have allowed us to identify some grains as detrital in the ion-milled samples. Yet, the absence of these characteristics cannot be considered as indicative of an authigenic origin. In all the cases in which such a detrital origin might be assumed, the composition was typically that of muscovite ( $\sum$ interlayer $\approx 1$ atom per formula unit, $a p f u$, and "low" $\mathrm{Si}$ and $\mathrm{Fe}+\mathrm{Mg}$ ). Nonetheless, such compositions are also present in $\mathrm{P} \beta-94$, where the correlation between them and the textural features on this sample at SEM and TEM scales, e.g., parallel packets with a well-developed crenulation cleavage and euhedral shapes, demonstrate the absence of detrital phyllosilicates.

In spite of the afore-mentioned heterogeneous compositions, two main chemical characteristics may be recognized in all samples: 1) $\mathrm{Na}$ is an abundant interlayer cation. In addition to the presence of $\mathrm{Na}-\mathrm{K}$ intermediate mica in all samples (with the exception of $\mathrm{P} \beta-94$, see Table 4), $\mathrm{Na}$ is generally present and, in some cases, fairly enriched in K-rich dioctahedral mica (Table 3), whereas Ca is invariably $0.01 \mathrm{apfu}$. Paragonite

TABL.E 2. WHOLE-ROCK COMPOSITIONS OF DIAGENETIC-METAMORPHIC ROCKS OF THE SOUTH PORTUGUESE ZONE, PORTUGAL

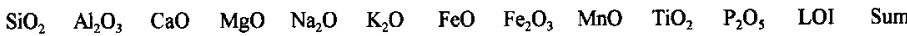

\begin{tabular}{|c|c|c|c|c|c|c|c|c|c|c|c|c|c|}
\hline \multicolumn{14}{|c|}{ Brejeira Formation } \\
\hline Pa-l & 57.5 & 22.5 & 0.11 & 1.49 & 0.67 & 4.17 & 1.2 & 4.44 & 0.24 & 0.99 & 0.08 & 5.54 & 99.2 \\
\hline Pc-9 & 72.3 & 18.4 & - & 0.29 & 0.56 & 2.77 & - & 1.23 & - & 0.94 & 0.1 & 4.23 & 100.4 \\
\hline Pd-14 & 64.5 & 22.6 & - & 0.4 & 0.85 & 3.77 & 0.1 & 1.23 & 0.12 & 1.06 & 0.05 & 5.39 & 100.1 \\
\hline Pe-16 & 61.5 & 20.2 & 1.0 & 1.4 & 0.83 & 3.56 & 3.9 & 0.75 & - & 0.96 & 0.07 & 5.62 & 100.5 \\
\hline Pf-21 & 59.6 & 26.2 & - & 0.38 & 0.67 & 4.51 & 0.1 & 0.35 & - & 1.28 & 0.06 & 6.77 & 100.1 \\
\hline $\mathrm{Pg}-27$ & 60.9 & 22.7 & - & 0.37 & 0.52 & 3.98 & 0.3 & 4.42 & 0.14 & 1.18 & 0.08 & 5.77 & 100.4 \\
\hline $\mathrm{Ph}-31$ & 56.5 & 26.0 & - & 0.53 & 0.84 & 4.6 & 0.2 & 2.25 & - & 1.15 & 0.08 & 6.77 & 99.1 \\
\hline \multicolumn{14}{|c|}{ Mira Formation } \\
\hline $\mathrm{Pi}-32$ & 58.0 & 20.6 & - & 1.64 & 1.21 & 2.99 & 1.8 & 4.96 & - & 1.02 & 0.11 & 6.54 & 99.2 \\
\hline $\mathrm{Pj}-37$ & 55.6 & 20.6 & - & 1.71 & 1.09 & 3.3 & 3.1 & 3.93 & 0.16 & 0.96 & 0.07 & 8.7 & 99.6 \\
\hline Pk-43 & 59.3 & 22.3 & 0.05 & 1.71 & 0.95 & 3.71 & 3.4 & 1.67 & 0.26 & 0.96 & 0.11 & 5.62 & 100.3 \\
\hline Pm-49 & 60.3 & 20.2 & 0.18 & 1.88 & 0.92 & 3.23 & 2.8 & 3.83 & 0.08 & 0.88 & 0.19 & 5.31 & 100.4 \\
\hline Pn-54 & 54.1 & 22.6 & 0.09 & 1.24 & 0.96 & 3.71 & 1.0 & 8.21 & 0.12 & 1.0 & 0.11 & 6.77 & 100.1 \\
\hline Po-56 & 59,3 & 21.1 & - & 1.77 & 0.88 & 3.71 & 2.7 & 1.99 & 0.14 & 0.97 & 0.04 & 6.31 & 99.5 \\
\hline \multicolumn{14}{|c|}{ Mértola Formation } \\
\hline Pp-61 & 63.0 & 15.3 & 5.63 & 0.99 & 1.29 & 2.72 & 0.3 & 2.75 & 0.11 & 1.29 & 3.4 & 3.93 & 100.0 \\
\hline Pp-63 & 58.9 & 19.6 & 0.14 & 2.56 & 0.9 & 3.55 & 5.3 & 1.27 & 0.13 & 0.84 & 0.12 & 5.16 & 99.2 \\
\hline$P q-65$ & 58.8 & 20.4 & 0.11 & 2.35 & 0.48 & 3.7 & 1.0 & 5.79 & - & 0.92 & 0.09 & 6.47 & 100.5 \\
\hline Ps-71 & 48.5 & 27.1 & 0.24 & 2.9 & 0.46 & 6.0 & 5.2 & 1.88 & - & 1.04 & 0.18 & 5.62 & 100.3 \\
\hline $\mathrm{Pu}-76$ & 63.8 & 18.1 & 0.2 & 2.3 & 1.5 & 2.92 & 3 & 2.81 & 0.08 & 0.84 & 0.12 & 4.47 & 100.6 \\
\hline \multicolumn{14}{|c|}{ Phyllite-Quartzite Formation } \\
\hline Pw-81 & 53.0 & 27.0 & 0.11 & 1.67 & 0.88 & 5.14 & 3.3 & 2.07 & 0.09 & 1.04 & 0.08 & 5.54 & 100.5 \\
\hline$P x-83$ & 72.8 & 12.8 & 0.02 & 1.0 & 0.58 & 2.04 & 1.2 & 4.3 & 0.65 & 0.84 & 0.09 & 3,85 & 99.9 \\
\hline$P x-85$ & 58.5 & 22.1 & - & 1.04 & 0.59 & 4.61 & - & 6.79 & 0.07 & 1.08 & 0.09 & 4.54 & 100.2 \\
\hline \multicolumn{14}{|c|}{ Pulo do Lobo Formation } \\
\hline $\mathrm{Pz}-89$ & 55.4 & 23.6 & 0.17 & 1.55 & 0.48 & 4.91 & 0.8 & 5.62 & - & 1.03 & 0.1 & 6.16 & 100.1 \\
\hline$P \beta-94$ & 50.7 & 24.4 & 0.15 & 2.12 & 0.72 & 4.88 & 1.2 & 7.22 & - & 0.89 & 0.08 & 7.23 & 100.1 \\
\hline Pó-96 & 74.2 & 12.7 & 0.15 & 0.88 & 1.55 & 1.82 & 0.2 & 3.83 & - & 0.74 & 0.09 & 3.77 & 1002 \\
\hline
\end{tabular}

The bulk compositions are reported in wt \% oxides. LOI: loss on ignition. 
has been qualitatively analyzed in a few cases in $\mathrm{Pk}-43$. 2) The phengitic component of the dioctahedral mica is very low. This fact can be appreciated both from the low $\mathrm{Fe}+\mathrm{Mg}$ content and the lack of correlation between this chemical parameter and the Si content. In the intermediate $\mathrm{Na}-\mathrm{K}$ mica, the phengitic component is lower than in the K-rich dioctahedral micas and the sum of interlayer cations is generally high. Ca was recorded in only two cases (sample Pc-9, $\leq 0.03 a p f u$ ).

Si does not significantly exceed values of $3 a p f u$ and where it does, it is generally related to a low sum of interlayer cations. A negative correlation $(r=0.60)$ between these two parameters has been calculated. In any
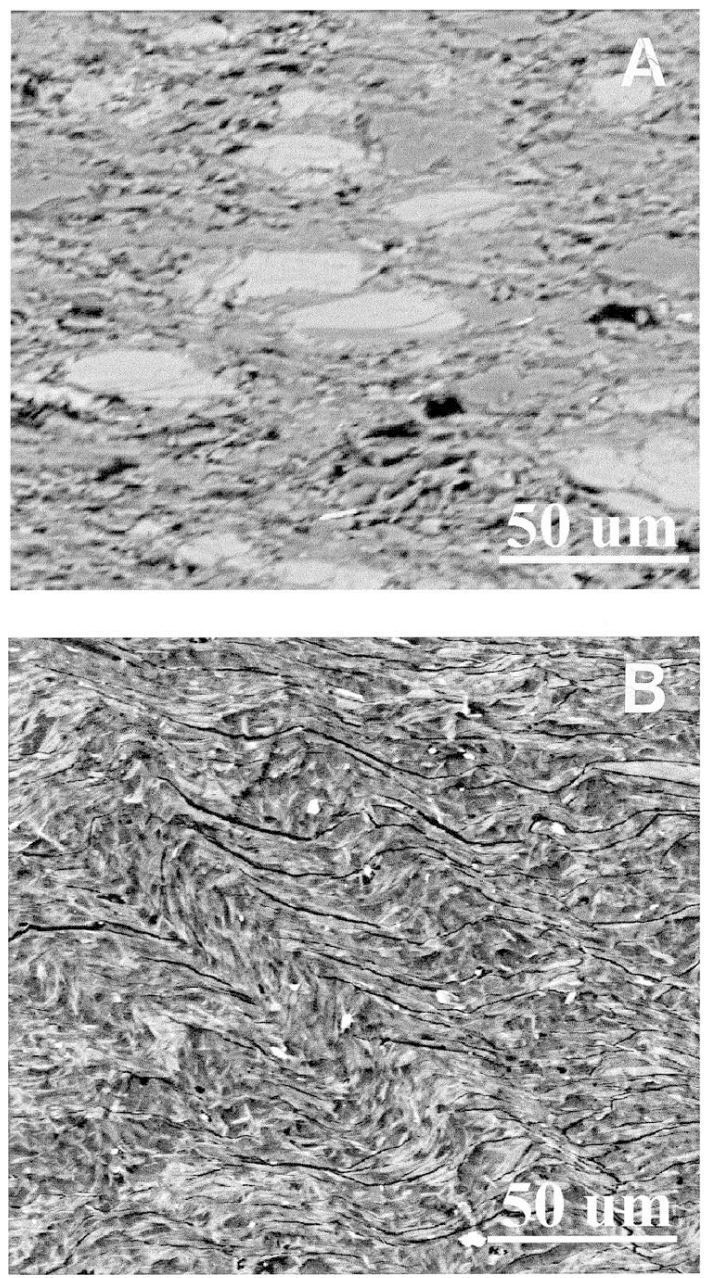

FIG. 4. A) BSE image showing the characteristic texture of sample $\mathrm{Pk}-43$ with chlorite-mica stacks and no signs of deformation. B) Representative BSE image of sample Pw81 , in which cleavage due to metamorphic deformation is obvious. case, this illitic component is only present in a minority of the samples (Fig. 9) and could be overestimated owing to analytical problems such as the loss of alkalis.

\section{AEM data on chlorite}

The same chemical heterogeneity described for dioctahedral micas is present in chlorite, noted in two samples (Table 5, Fig. 10). Both samples are rich in Fe, but $\mathrm{Pw}-81$ is richer in $\mathrm{Fe}$ and in $\mathrm{Si}$ than $\mathrm{Pk}-43$. Differences in the $\mathrm{Al}: \mathrm{Mg}$ ratio are less significant, albeit slightly lower for Pk-43 (Fig. 10A).

Another significant chemical characteristic of the chlorite is their high sum of octahedral cations, which in many cases produce apparent values slightly higher than 6 (Table 5). The values are a consequence of normalization considering all $\mathrm{Fe}$ as $\mathrm{Fe}^{2+}$, and demonstrates the presence of some undetermined quantities of $\mathrm{Fe}^{3+}$ in the chlorite analyzed.

\section{DISCUSSION}

\section{X-ray-diffraction data versus TEM data}

Various XRD parameters reveal some of the physical and chemical characteristics of the phyllosilicates.

TABLE 3. REPRESENTATIVE AEM DATA FOR K-RICH DIOCTAHEDRAL MICAS IN DIAGENETIC-METAMORPHIC ROCKS OF THE SOUTH PORTUGUESE ZONE, PORTUGAL

\begin{tabular}{|c|c|c|c|c|c|c|c|c|c|c|}
\hline Pc-9 m5 & 2.99 & 1.01 & 1.89 & 0.05 & 0.14 & 0.00 & 2.09 & 0.73 & 0.21 & 0.94 \\
\hline Pc-9 m7 & 3.09 & 0.91 & 1.92 & 0.03 & 0.10 & 0.00 & 2.05 & 0.75 & 0.14 & 0.89 \\
\hline Pc-9 m8 & 3.08 & 0.92 & 1.93 & 0.03 & 0.12 & 0.00 & 2.08 & 0.71 & 0.13 & 0.84 \\
\hline Pc-9 7 & 3,08 & 0.92 & 1.77 & 0.08 & 0.18 & 0.00 & 2.04 & 1.01 & 0.06 & 1.06 \\
\hline Pc-9 13 & 3.18 & 0.82 & 1.93 & 0.02 & 0.14 & 0.00 & 2.09 & 0.57 & 0.15 & 0.71 \\
\hline Pc-9 15 & 3.45 & 0.55 & 1.91 & 0.03 & 0.06 & 0.00 & 2.00 & 0.52 & 0.11 & 0.63 \\
\hline Pc-9 17 & 3.22 & 0.78 & 1.88 & 0.05 & 0.08 & 0.00 & 2.01 & 0.76 & 0.12 & 0.88 \\
\hline Pk-43 m3 & 3.24 & 0,76 & 1.85 & 0.11 & 0.13 & 0.00 & 2.09 & 0.72 & 0.00 & 0.72 \\
\hline $\mathrm{Pk}-43 \mathrm{~m} 6$ & 2.99 & 1,01 & 1.90 & 0.04 & 0.09 & 0.01 & 2.04 & 0.82 & 0.18 & 1.00 \\
\hline $\mathrm{Pk}-438$ & 3.36 & 0.64 & 1.78 & 0.10 & 0.15 & 0.00 & 2.03 & 0.72 & 0.07 & 0.80 \\
\hline Pk-43 11 & 3.31 & 0.69 & 1.90 & 0.05 & 0,09 & 0.00 & 2.04 & 0.56 & 0.15 & 0.71 \\
\hline Pk-43 2 & 3.18 & 0.82 & 1.74 & 0.07 & 0.28 & 0.00 & 2.09 & 0.80 & 0.11 & 0.91 \\
\hline$P w-8 \operatorname{lm} 1$ & 3.15 & 0.85 & 1.81 & 0.09 & 0.12 & 0.01 & 2.03 & 0.79 & 0.17 & 0.96 \\
\hline Pw-81m4 & 3.03 & 0.97 & 1.88 & 0.05 & 0.13 & 0.01 & 2.06 & 0.82 & 0.13 & 0.95 \\
\hline Pw-81ms & 3.05 & 0.95 & 1.88 & 0.03 & 0.09 & 0.01 & 2.01 & 0.86 & 0.17 & 1.03 \\
\hline Pw-81m9 & 3.12 & 0.88 & 1.93 & 0.03 & 0.07 & 0.01 & 2.04 & 0.75 & 0.12 & 0.87 \\
\hline Pw-81m10 & 2.98 & 1.02 & 1.86 & 0.03 & 0.12 & 0.01 & 2.02 & 0.99 & 0.10 & 1.09 \\
\hline Pw-81m11 & 3.05 & 0.95 & 1.91 & 0.04 & 0.09 & 0.01 & 2.05 & 0.93 & 0.00 & 0.93 \\
\hline Pw-81 3 & 2.99 & 1.01 & 1.76 & 0.07 & 0.23 & 0.00 & 2.06 & 0.95 & 0.15 & 1.12 \\
\hline Pw-81 5 & 3.15 & 0.85 & 1.86 & 0.05 & 0.17 & 0.00 & 2.08 & 0.70 & 0.13 & 0.83 \\
\hline Pw-81 19 & 3.06 & 0.94 & 1.94 & 0.04 & 0.04 & 0.00 & 2.02 & 0.77 & 0.18 & 0.95 \\
\hline Pw-81 20 & 3.31 & 0.69 & 1.79 & 0.07 & 0.08 & 0.00 & 1.93 & 0.90 & 0.13 & 1.03 \\
\hline$P \beta-9429$ & 3.08 & 0.92 & 1.91 & 0.07 & 0.07 & 0.00 & 2.05 & 0.79 & 0.11 & 0.90 \\
\hline$P \beta-9424$ & 3.05 & 0.95 & 1.85 & 0.10 & 0.13 & 0.00 & 2.08 & 0.78 & 0.15 & 0.93 \\
\hline$P(\beta-9422$ & 2.99 & 1.01 & 1.90 & 0.06 & 0.10 & 0.00 & 2.06 & 0.80 & 0.20 & 1.00 \\
\hline$P \beta-948$ & 3.32 & 0.68 & 1.79 & 0.10 & 0,06 & 0.00 & 1.96 & 0.97 & 0.00 & 0.97 \\
\hline$P \beta-947$ & 3.29 & 0.71 & 1.88 & 0.06 & 0.06 & 0.00 & 2.00 & 0.77 & 0.06 & 0.83 \\
\hline$P \beta-946$ & 3.27 & 0.73 & 1.74 & 0.10 & 0.11 & 0.00 & 1.96 & 1.01 & 0.07 & 1.08 \\
\hline$P \beta-941$ & 3.33 & 0.67 & 1.83 & 0.07 & 0.09 & 0.00 & 2.00 & 0.84 & 0.00 & 0.84 \\
\hline$P \beta-944$ & 3.26 & 0.74 & 1.86 & 0.06 & 0.04 & 0.00 & 1.96 & 0.88 & 0.09 & 0.96 \\
\hline
\end{tabular}




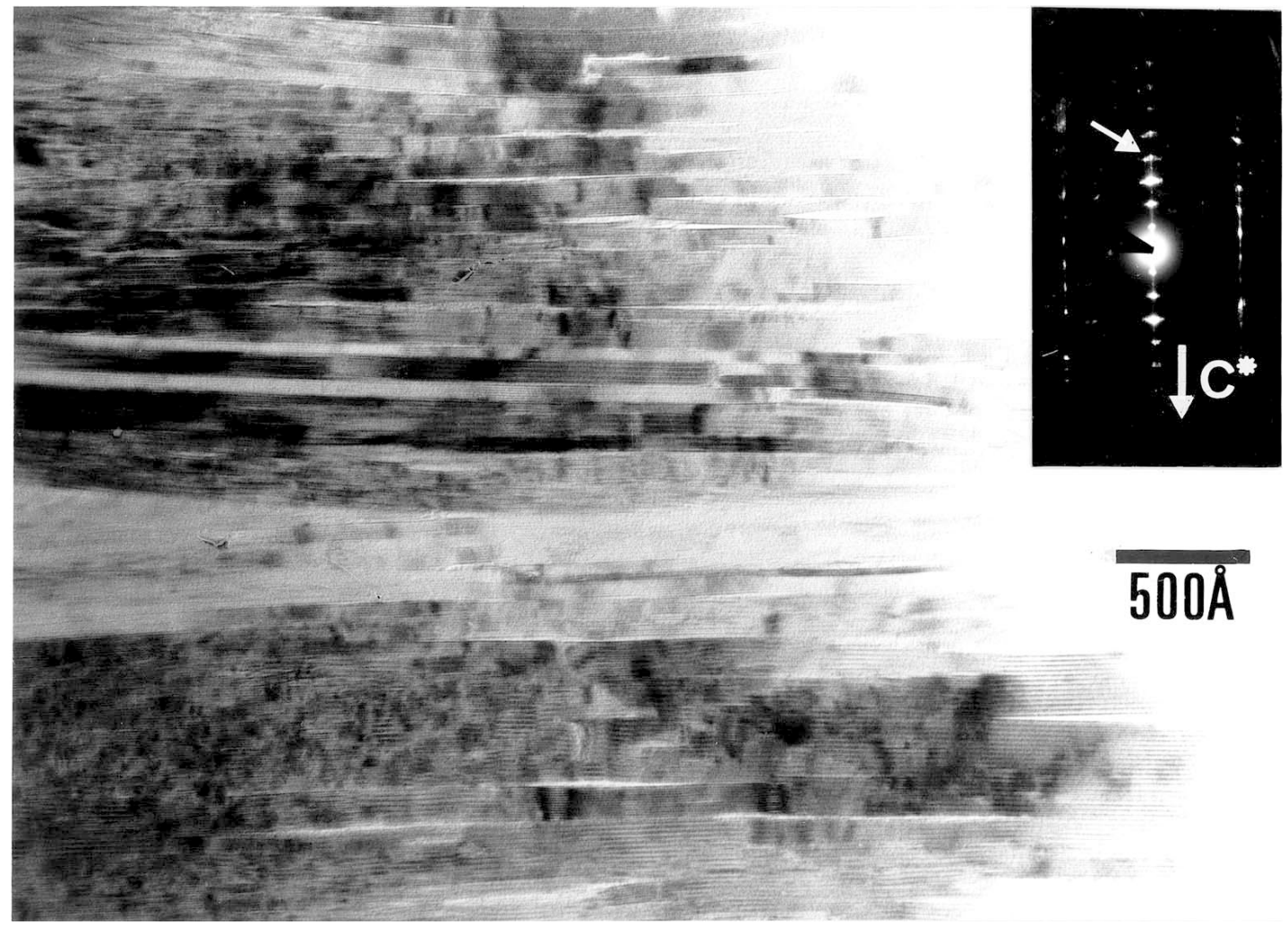

FIG. 5. Lattice-fringe image of an area from sample Pc-9 with a composition of mica having similar contents of Na and K, displaying lenticular pores typical of Na-rich dioctahedral mica. No differences in Na: $\mathrm{K}$ ratio have been detected among different packets. The electron-diffraction pattern shows sharp $00 l$ reflection of mica. The dynamic effect allows the recognition of a $2 M$ polytype.

TABLF 4 AEM DATA FOR INTERMEDIATE Na-K MICAS IN DIAGENETIC-METAMORPHIC ROCKS

OF THE SOUTH PORTUGUESE ZONE, PORTUGAL

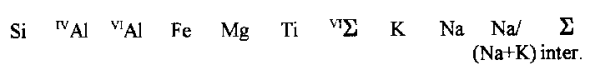

$\begin{array}{llllllllllll}\text { Pc-9 1 } & 3.06 & 0.94 & 1.91 & 0.03 & 0.10 & 0.01 & 2.05 & 0.67 & 0.27 & 0.28 & 0.94\end{array}$

$\begin{array}{llllllllllll}\text { Pc-9 } 2 & 3.00 & 1.00 & 1.93 & 0.03 & 0.09 & 0.01 & 2.05 & 0.68 & 0.28 & 0.29 & 0.96\end{array}$

$\begin{array}{lllllllllllll}\text { Pc-9 } 3 & 3.10 & 0.90 & 1.92 & 0.01 & 0.11 & 0.01 & 2.05 & 0.51 & 0.38 & 0.43 & 0.88\end{array}$

$\begin{array}{llllllllllllll}\text { Pc-9 } 5 & 3.02 & 0.98 & 1.88 & 0.03 & 0.15 & 0.01 & 2.06 & 0.72 & 0.27 & 0.27 & 0.99\end{array}$

$\begin{array}{lllllllllllll}\text { Pc-9 4 } & 3.20 & 0.80 & 1.90 & 0.02 & 0.13 & 0.01 & 2.05 & 0.51 & 0.29 & 0.36 & 0.80\end{array}$

$\begin{array}{llllllllllllll}\text { Pc-9 } 16 & 3.13 & 0.87 & 1.94 & 0.02 & 0.06 & 0.01 & 2.01 & 0.59 & 0.30 & 0.33 & 0.90\end{array}$

$\begin{array}{llllllllllll}\text { Pc-9 } 18 & 3.20 & 0.80 & 1.88 & 0.02 & 0.06 & 0.01 & 1.97 & 0.57 & 0.35 & 0.38 & 0.95\end{array}$

$\begin{array}{llllllllllll}\text { Pk-43 1 } & 3.11 & 0.89 & 1.90 & 0.05 & 0.14 & 0.01 & 2.08 & 0.54 & 0.28 & 0.34 & 0.82\end{array}$ $\begin{array}{lllllllllllllll}\text { Pk-43 } 3 & 3.12 & 0.88 & 1.83 & 0.09 & 0.16 & 0.01 & 2.07 & 0.45 & 0.45 & 0.50 & 0.90\end{array}$ $\begin{array}{llllllllllll}\text { Pk-43 } 4 & 3.20 & 0.80 & 1.86 & 0.07 & 0.14 & 0.01 & 2.07 & 0.49 & 0.31 & 0.39 & 0.80\end{array}$ $\begin{array}{llllllllllllll}\text { Pk-43 } 5 & 3.04 & 0.96 & 1.94 & 0.03 & 0.09 & 0.00 & 2.06 & 0.66 & 0.25 & 0.27 & 0.91\end{array}$

$\begin{array}{llllllllllll}\text { Pw-81 }_{\text {W }} & 3.03 & 0.97 & 1.91 & 0.05 & 0.10 & 0.01 & 2.07 & 0.46 & 0.44 & 0.49 & 0.90\end{array}$ $\begin{array}{lllllllllllll}\mathrm{P} w-81 & 3.01 & 0.99 & 1.86 & 0.10 & 0.07 & 0.01 & 2.04 & 0.57 & 0.47 & 0.45 & 1.04\end{array}$ $\begin{array}{llllllllllll}\text { Pw-81 } 3 & 3.15 & 0.85 & 1.85 & 0.07 & 0.09 & 0.00 & 2.01 & 0.61 & 0.37 & 0.38 & 0.98\end{array}$ $\begin{array}{lllllllllllll}\text { Pw-81 } 4 & 3.02 & 0.98 & 1.93 & 0.03 & 0.08 & 0.00 & 2.04 & 0.49 & 0.48 & 0.49 & 0.96\end{array}$ $\begin{array}{llllllllllll}\text { Pw-81 } 5 & 3.05 & 0.95 & 1.90 & 0.04 & 0.12 & 0.01 & 2.07 & 0.52 & 0.37 & 0.42 & 0.88\end{array}$

The data are normalized to $\mathrm{O}_{10}(\mathrm{OH})_{2} ;$ values in atoms per formula unit (apfu)
TABLE 5. REPRESENTATIVE AEM DATA FOR CHLORITE IN DIAGENETIC-METAMORPHIC ROCKS OF THE SOUTH PORTUGUESE ZONE, PORTUGAL

\begin{tabular}{|c|c|c|c|c|c|c|c|c|c|c|}
\hline & $\mathrm{Si}$ & ${ }^{\mathrm{N}} \mathrm{Al}$ & $\left.{ }^{\mathrm{V}} \mathrm{A}\right]$ & $\mathrm{Fe}$ & $\mathrm{Mg}$ & $\mathrm{Mn}$ & $\mathrm{Ti}$ & ${ }^{\mathrm{v}} \Sigma$ & Al tot & $\begin{array}{r}\mathrm{Fe} /(\mathrm{Fe} \\
+\mathrm{Mg})\end{array}$ \\
\hline $\mathrm{Pk}-43 \mathrm{cl}$ & 2.57 & 1.43 & 1,58 & 2.62 & 1.72 & 0.01 & 0.00 & 5.93 & 3.01 & 0.60 \\
\hline Pk-43 c2 & 2.57 & 1.43 & 1.43 & 2.95 & 1.59 & 0.03 & 0.00 & 6.00 & 2.86 & 0.65 \\
\hline Pk-43 c3 & 2.55 & 1.45 & 1.40 & 3.07 & 1.52 & 0.04 & 0.00 & 6.03 & 2.85 & 0.67 \\
\hline $\mathrm{Pk}-43 \mathrm{c} 4$ & 2.62 & 1.38 & 1.48 & 2.84 & 1.60 & 0.03 & 0.00 & 5.95 & 2.86 & 0.64 \\
\hline Pk-43 4 & 2.44 & 1.56 & 1.46 & 2.76 & 1.82 & 0.00 & 0.00 & 6.05 & 3.03 & 0.60 \\
\hline Pk-43 5 & 2.41 & 1.59 & 1.40 & 2.93 & 1.77 & 0.00 & 0.00 & 6.10 & 2.99 & 0.62 \\
\hline Pw-8lcl & 2.65 & 1.35 & 1.58 & 2.88 & 1.38 & 0.05 & 0.00 & 5.89 & 2.93 & 0.68 \\
\hline Pw-8lc5 & 2.52 & 1.48 & 1.48 & 3.03 & 1.44 & 0.05 & 0.00 & 6.00 & 2.96 & 0.68 \\
\hline Pw-8lc6 & 2.70 & 1.30 & 1.46 & 2.83 & 1.53 & 0.05 & 0.02 & 5.87 & 2.77 & 0.65 \\
\hline Pw-81c8 & 2.66 & 1.34 & 1.63 & 2.83 & 1.36 & 0.03 & 0.00 & 5.85 & 2.97 & 0.67 \\
\hline Pw-81 11 & 2.64 & 1.36 & 1.68 & 2.91 & 1.24 & 0.00 & 0.00 & 5.84 & 3.04 & 0.70 \\
\hline Pw-81 13 & 2.50 & 1.50 & 1.27 & 3.65 & 1.20 & 0.00 & 0.00 & 6.12 & 2.76 & 0.75 \\
\hline Pw-81 17 & 2.52 & 1.48 & 1.43 & 3.48 & 1.11 & 0.00 & 0.00 & 6.03 & 2.92 & 0.76 \\
\hline
\end{tabular}

The data are normalized to $\mathrm{O}_{10}(\mathrm{OH})_{8}$; values in atoms per fonnula unit (apfu) 
The IC parameter is related to the thickness of crystallites of mica (e.g., Warr \& Nieto 1998, Li et al. 1998). The cell parameters and the $(00 l)$ intensity ratios reflect various chemical substitutions (e.g., Guidotti et al. 1992, Rausell-Colom et al. 1991, Shata et al. 1998). Nevertheless, this is an indirect approach, also dependent on other variables, and gives an average value for the entire sample, neglecting differences among grains. Therefore, direct data obtained from lattice-fringe images and AEM of carefully selected samples are fundamental. In particular, very-low-grade samples are characterized by a generalized lack of textural and chemical equilibrium (see "Introduction"). It is particularly important to check to which extent an average value is representative of the overall sample. Below, we compare equivalent characteristics obtained by the XRD and TEM methods.
A good correlation between mineral composition determined by XRD (Table 1) and electron microscopy has been found. All the phases identified in the XRD diagrams have been recognized in lattice-fringe images of the very fine-grained matrix of the samples, by selected-area electron diffraction and analytical electron microscopy.

In relation to the illite-crystallinity data, samples Pc9 and $\mathrm{Pk}-43$ present very similar values of IC, with a slightly higher value for the latter sample, even though they are separated by more than $50 \mathrm{~km}$ and belong to different geological formations. Figure 2 shows lower values of IC toward the northeast, but the evolution of this parameter is not strictly progressive; rather, it shows a few abrupt changes, e.g., within the upper Brejeira Formation and, especially, at the boundary between
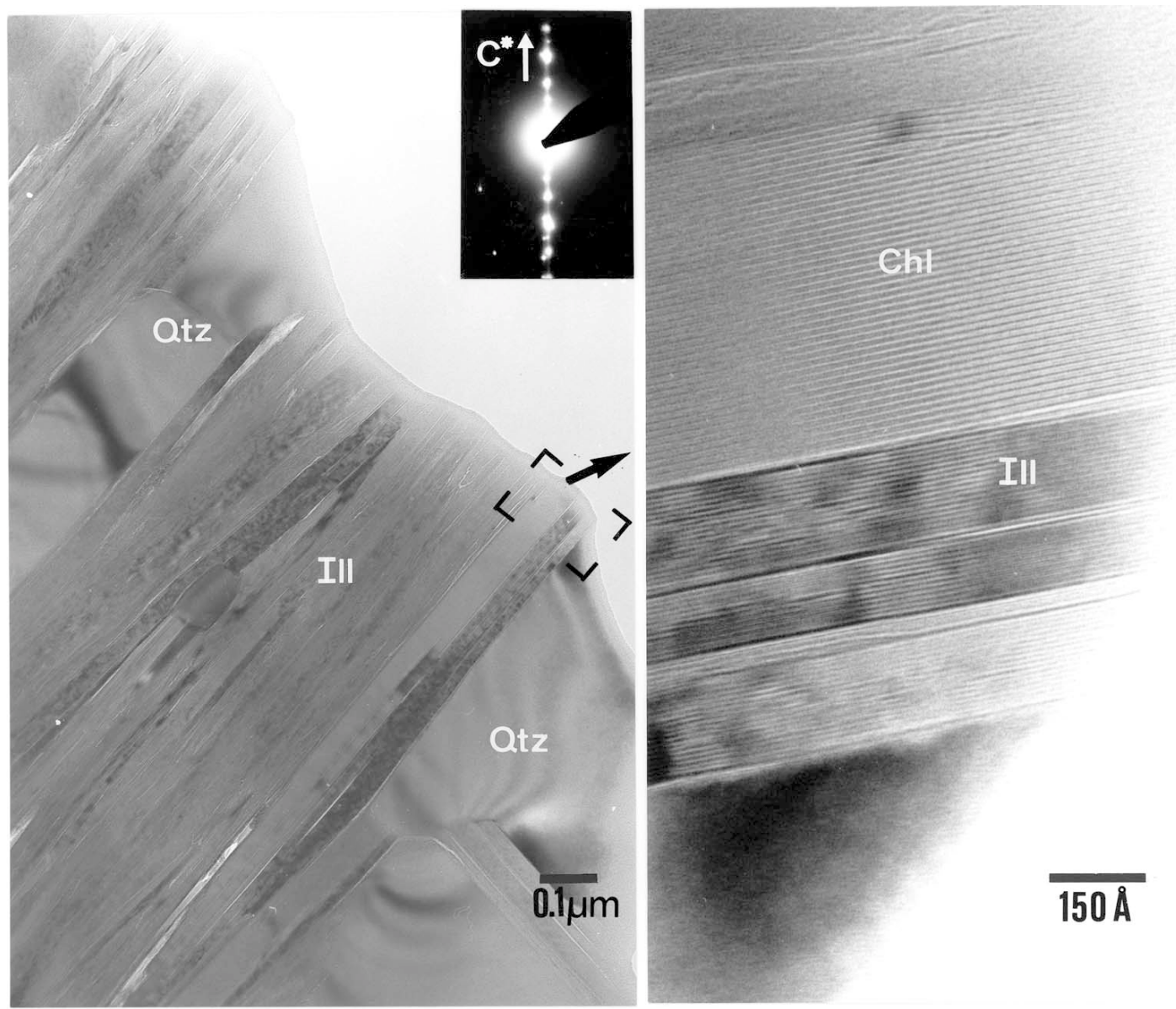

FIG. 6. TEM image that shows the general texture of an area of chlorite-illite intergrowth in sample Pk-43. The enlarged area on the right shows the relationship between mica and chlorite. The mica crystals, where observed in detail, are seen to be formed by smaller slightly misoriented crystals. Both chlorite and mica reflections are present in the SAED. 

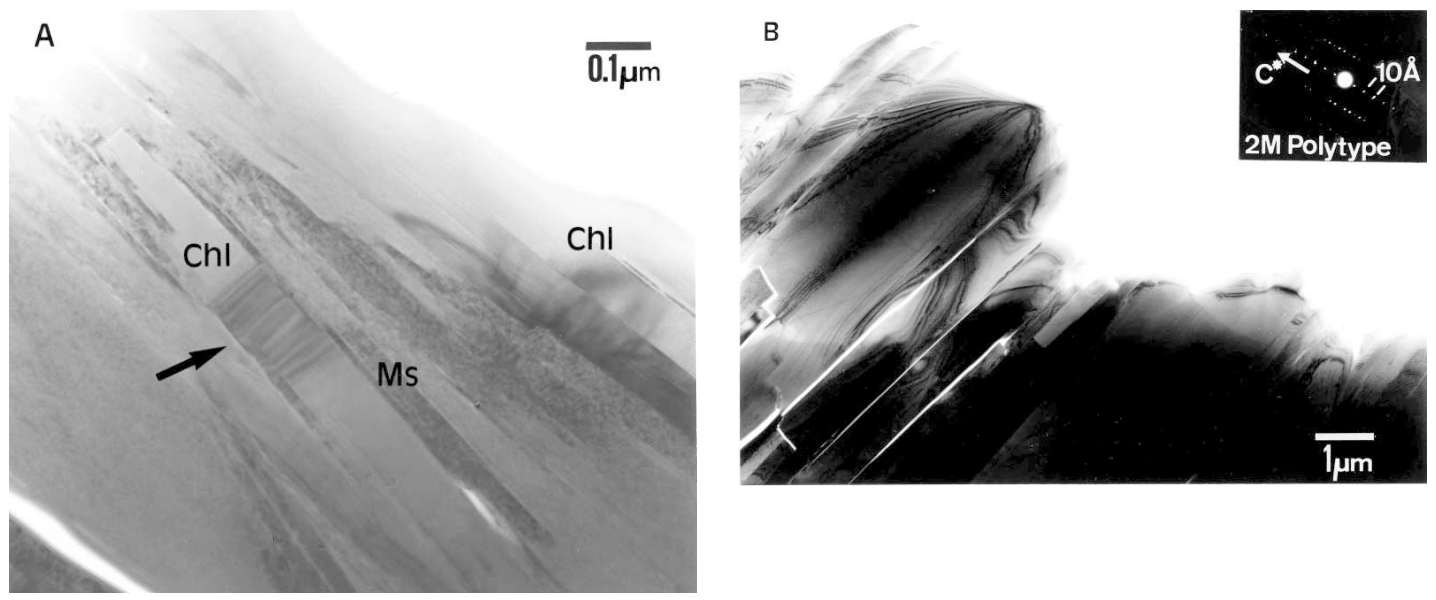

FIG. 7. A) Lattice-fringe image of chlorite and muscovite crystals from anchizonal sample Pw-81. Chlorite crystals show deformation features as kink bands and bent layers (see arrow). B) TEM image of muscovite crystals in epizonal sample P $\beta-$ 94. Most of the crystals are thicker than $1000 \AA$.

Mira and Mértola formations. Its general evolution is stepwise rather than continuous. To check whether this kind of evolution really represents the change in crystallite thicknesses or if it is more closely related to other factors, for example the presence of paragonitic components in the rocks, the two most widely separated samples of the first IC interval (Pc-9 and Pk-43) were selected for the TEM study, and their crystallite thicknesses were measured directly from lattice-fringe images (Fig. 8). The results show a good correlation with the value of IC; $\mathrm{Pk}-43$ presents slightly smaller crystallites than Pc-9, and they both correspond to the highgrade diagenetic zone, although the real thickness of the crystallites is more typical of the low anchizone (Merriman \& Peacor 1999). Anchizone sample Pw-81 produces two maxima, possibly as a result of tectonic strain in the mica crystals (Merriman et al. 1995, Árkai et al. 1997, Giorgetti et al. 2000), though its average thickness is higher than in the diagenetic samples; epizone sample $\mathrm{P} \beta-94$ shows the largest thicknesses. Therefore, the effect of paragonite on the IC value is small. Nevertheless, the relationships among the four samples are the same for both the IC and TEM methods.

Guidotti et al. (1992) studied the compositional controls on the cell dimensions of muscovite. They found that both phengitic and paragonitic substitutions affect the $b$ parameter and basal spacing, $d_{001}$, and proposed a diagram relating these two XRD-based parameters with those substitutions in micas. Our samples show a low $b$ and high $d_{001}$, with no significant differences among samples or fractions (Table 1). When represented in the diagram of Guidotti et al. (1992, Fig. 4b), our analyses define a field very close to the $\mathrm{Fm}=0$ line and near the
$\mathrm{Na} /(\mathrm{Na}+\mathrm{K})=0.1$ area. AEM analyses (Table 3) produce similar results, but compositions of K-rich dioctahedral mica are very different from grain to grain. Nevertheless, the phengitic component, although small, is not zero, and the Na content is slightly higher than $10 \%$ in the interlayer positions. Therefore, a broad correlation exists between the XRD parameters and AEM data, but these very-low-grade samples show slightly higher $d_{001}$ and lower $b$ than expected from their chemical compositions. The effect of illitic substitution was not considered by Guidotti et al. (1992), and therefore the illitic influence on these small differences is difficult to evaluate.

Nieto (1997) related the $b$ parameter of chlorite with its $\mathrm{Fe}$ content. In addition, his results on the relationship between substitution in the tetrahedral site and $d_{001}$ coincide with those of Rausell-Colom et al. (1991). The combined use of equations in Nieto (1997) and RausellColom et al. (1991) allows one to evaluate the two most important isomorphic substitutions in chlorite, that is, $\mathrm{FeMg}_{-1}$ and Tschermak substitutions, from XRD parameters. Its application to the chlorite parameters of samples $\mathrm{Pk}-43$ and $\mathrm{Pw}-81$ (Table 1) produces results in the range of chemical compositions found by AEM (Table 4). In relation to average AEM values, XRD results produce lower proportions of $\mathrm{Fe}$ and ${ }^{\mathrm{IV}} \mathrm{Al}$. The effect of other minor substitutions, such as $\mathrm{Fe}^{3+} / \mathrm{Fe}^{2+}$, dioctahedral/trioctahedral or $\mathrm{OH}^{-} / \mathrm{O}^{2-}$, may be responsible for these small differences, which in any case are within the error limits of both AEM and XRD methods.

In conclusion, XRD methods allow one to routinely obtain approximate data on large sets of samples and to define rock populations in order to choose the most representative samples for TEM study and AEM analyses, 

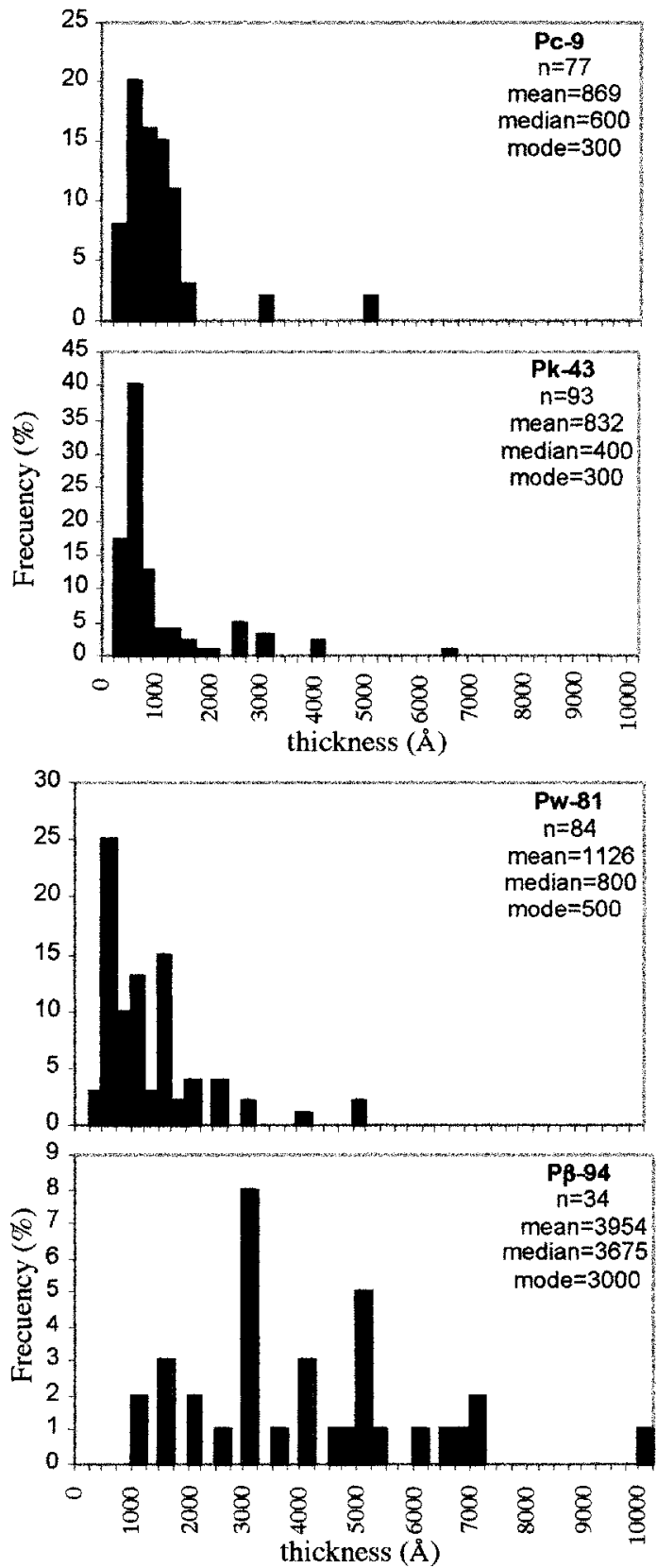

FIG. 8. Histogram showing the distribution of crystallite thickness of illite $10 \AA$ layers measured on lattice-fringe images.

which do produce direct results in relation to the textural and chemical characteristics of phyllosilicates and also information on the differences among different grains.
The resulting differences in texture among samples are clearly visible at the SEM scale (Figs. 4A, B). Lattice-fringe images and electron diffraction show similarities in mineralogy and texture for the anchizone samples. They are formed by an intergrowth of subparallel packets of $\mathrm{K}$ and $\mathrm{Na}$ micas and chlorite in the samples whose bulk compositions are consistent with this mineral phase $(\mathrm{Pk}-43$ and $\mathrm{Pw}-81)$. These packets contain numerous defects, such as dislocations, strain fields and layer terminations. Fewer defects and a larger size of packet are the only obvious differences between the low-anchizone samples ( $\mathrm{Pc}-9$ and $\mathrm{Pk}-43$ ) and the high-anchizone one $(\mathrm{Pw}-81)$. The texture of epizone sample $\mathrm{P} \beta-94$ is definitively different, with large, perfectly parallel defect-free packets of muscovite. All the samples contain the $2 M$ polytype of mica, and semirandom stacking polytypes for chlorite. Therefore, no qualitative differences appear until the epizone, where textural equilibrium is reached, as characterized by thick, straight, defect-free crystallites (Merriman \& Peacor 1999). Differences in thickness of crystallites and density of defects have been found only among the anchizone samples; the increase in crystal thickness and decrease in crystalline defects can be followed by means of the IC values. In fact, TEM lattice-fringe images reveal strain-induced defects that affected the phyllosilicates after their crystal growth (Fig. 7A).

Some of the crystals have been reduced to polygonized stacks of subgrains. As a consequence, the crystallite thicknesses of the anchizone samples were partially reduced, which is obvious in sample $\mathrm{Pw}-81$, with its bimodal distribution of thicknesses (Fig. 8). Nevertheless, this effect is absent in epizone sample $P \beta-94$, which consists of large, defect-free grains. These differences could be the result of the tectonic overprint that produced the development of the crenulation cleavage (Fig. 4B), giving rise to either a reduction or increase in crystallite thickness, according to the degree of tectonic stress (Merriman \& Frey 1999). In the instance where tectonic strain is higher than the rate of recrystallization, it would favor a reduction in thickness of phyllosilicate crystals (Giorgetti et al. 2000).

Chemically, all the dioctahedral micas are characterized by a significant lack of homogeneity. The phengite component is minor, although important differences have been detected in the illitic and paragonitic components (Fig. 9). Detrital micas could be responsible in part for these chemical differences, although not for the broad range of compositions found. Compositions similar to those of obvious detrital micas in lower-grade samples have also been found in sample $P \beta-94$, where they are clearly absent. Moreover, no difference exists between the compositional fields of clay fractions and bulk rocks, represented in the Rey \& Kübler (1983) triangle. The $(00 l)$ intensities define a broad range between muscovite-like and illite-like areas for all samples, but this range is the same for both kinds of fractions (Fig. 3). Both XRD, for the whole set of the samples, and AEM, 


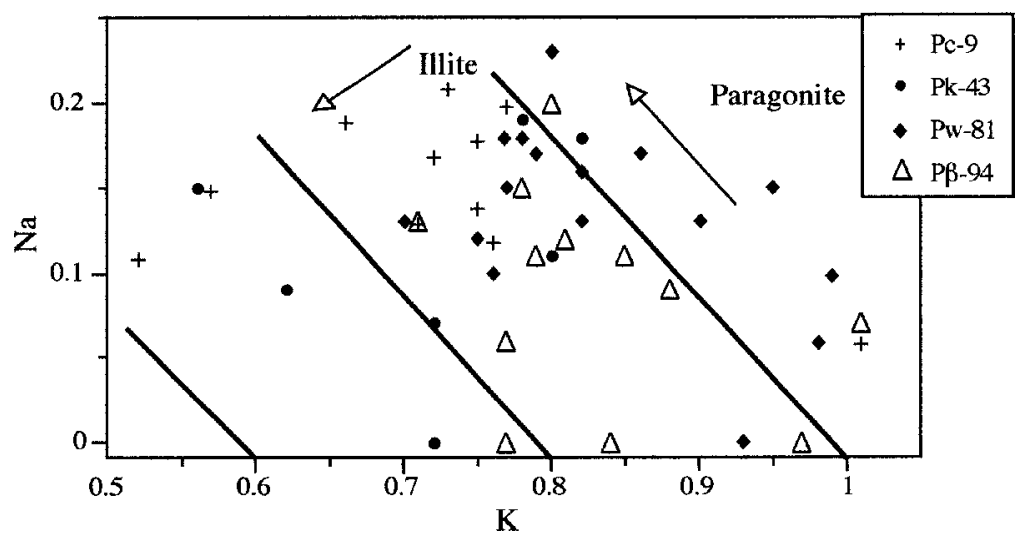

FIG. 9. Compositional diagram showing the $\mathrm{K}$ and $\mathrm{Na}$ contents of muscovite normalized to $\mathrm{O}_{10}(\mathrm{OH})_{2}$.

A

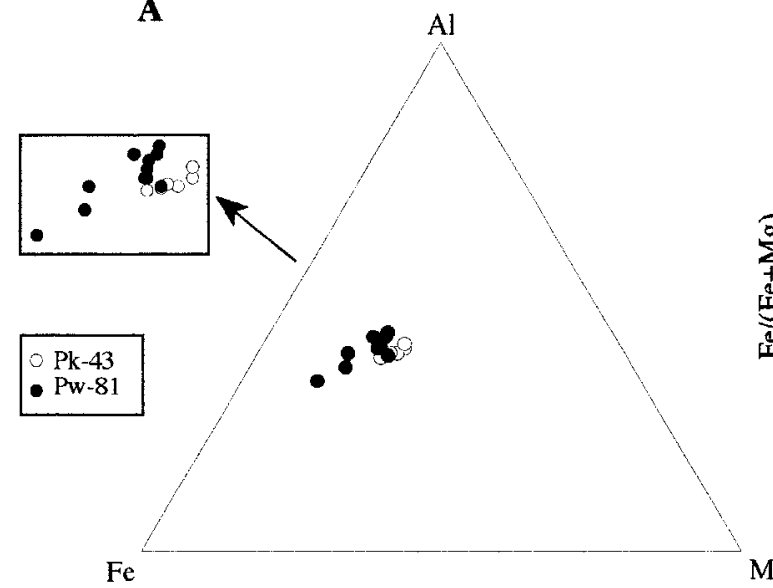

B

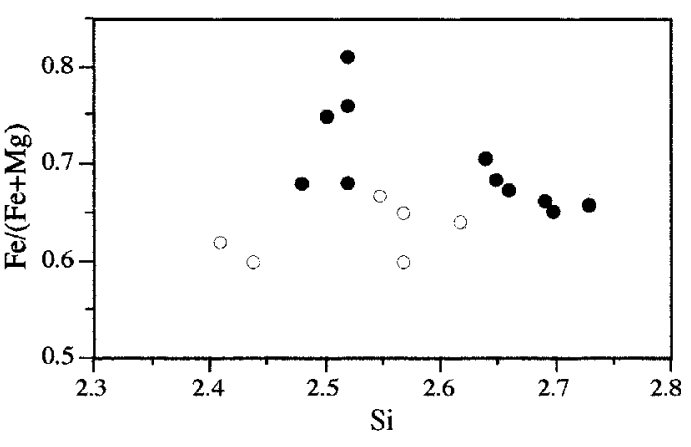

$\mathrm{Mg}$

FIG. 10. The composition of chlorite. A) Al-Fe-Mg diagram. B) Si versus $\mathrm{Fe} /(\mathrm{Fe}+\mathrm{Mg})$. Data obtained by AEM analyses and normalized to $\mathrm{O}_{10}(\mathrm{OH})_{8}$.

at the sample level, provide scattered values owing to the combined presence of illite and muscovite (Fig. 9). These two techniques reveal a tendency for the micas to be closer to muscovite and less to illite with increasing metamorphic grade, although both minerals are present in all the samples. A similar tendency toward a progressive compositional homogenization with concomitant substitution of illite-like by muscovite-like compositions of micas has been described by Livi et al. (1997) for Liassic shales of central Switzerland.

In addition to paragonite, the $\mathrm{Na}-\mathrm{K}$ micas have been recognized by XRD throughout the anchizone (Fig. 2). They present all the chemical and textural characteristics with which Jiang \& Peacor (1993) defined the in- termediate-composition nature of this kind of micas. Frey (1987) had postulated the existence of illite/ paragonite mixed-layers. On the basis of the absence of superlattice reflections in SAED or contrasts variable from layer to layer in lattice-fringe images, Jiang \& Peacor (1993) postulated the existence of metastable micas with intermediate composition within the miscibility gap between muscovite and paragonite. Nevertheless, Livi et al. (1997) argued that such micas cannot readily be distinguished from intimate mixtures of $\mathrm{Na}-$ and K-rich mica domains. Computer-image simulations would be necessary to check the possible differences in contrast in the lattice-fringe images between the muscovite and paragonite layers. 
In the Pulo do Lobo samples, albite is the Na-rich phase. No thermodynamic reasons exist for the absence of paragonite at this metamorphic grade. The alternative presence of the paragonite or albite is related with the proportion of $\mathrm{Al}$ in the system. Nevertheless, no clear differences related to this parameter have been found in the different areas of the SPZ (Table 2). According to Guidotti \& Sassi (1998), many of the compositional changes affecting micas in metamorphism are the result of reactions with fluids, and therefore highly dependent on the relative activities of $\mathrm{Na}^{+}, \mathrm{K}^{+}$and $\mathrm{H}^{+}$. A very similar trend of Na rich-micas to that described above was found by Merriman \& Roberts (1985) in the northern part of the Welsh Basin; the intermediate $\mathrm{Na}-$ $\mathrm{K}$ mica was found to have formed at a lower grade than the anchizone. Paragonite coexists with it at a slightly higher grade, and both kinds of micas are absent in the higher part of epizone, in which albite is the only Narich mineral.

The presence of chlorite in the samples and their compositions in the SPZ are highly affected by the hostrock composition (Tables 1,2 ). Chlorite is present only in samples with a higher $\mathrm{Fe}+\mathrm{Mg}$ content. In addition, sample $\mathrm{Pw}-81$ contains chlorite with higher Fe:Mg ratio than in $\mathrm{Pk}-43$ (Table 5), in accordance with the chemical compositions of the respective rocks (Table 2). On the basis of their extremely high $\Sigma$ octahedral cations, a significant proportion of $\mathrm{Fe}^{3+}$ has been inferred in the "Results" section, which is not unusual, as hematite is the primary opaque mineral in the samples. Zane et al. (1998) concluded that the composition trends of chlorite are strongly correlated with bulk-rock compositions and cannot be used as a geothermometer. De Caritat et al. (1993) noted that none of the chlorite thermometers give reliable temperatures over the range studied, and Essene \& Peacor (1995) interpreted the systematic variations of chlorite composition empirically found to vary with grade as being the result of contamination by other phyllosilicates.

\section{Low-grade metamorphism in the South Portuguese Zone}

Munhá (1983a) defined four metamorphic zones for the area studied, mainly based on the mineral assemblages of mafic metavolcanic rocks. Overall, these zones represent a decreasing metamorphic grade from greenschist-facies conditions to the northeast to prehnitepumpellyite facies or lower to the southwest. The exact minimum grade was not determined because of the absence of volcanic rocks in the southernmost zones.

Our study shows that mineral assemblages and the IC value of pelitic rocks (Fig. 2) obtained by XRD and confirmed by electron microscopy agree with the results of Munhá (1983a). The IC decreases from values around diagenetic-anchizone limit to the southwest to values typical of the epizone to the northeast, where the presence of volcanic rocks allows the correlation between metamorphic zones and IC zonation to be checked. The coincidence of epizone-type values with the greenschist facies and anchizone-type values with the prehnitepumpellyite facies (Fig. 2) agrees with the correlation between the two criteria found by Kisch (1987).

The continuity of the pelite outcrops has allowed us to complement Munhá's (1983a) description of the metamorphic zonation. First, the change in metamorphic grade is not progressive. Three different steps can be recognized in the IC evolution (Fig. 2). In the first one, late-diagenetic and low-anchizone values are predominant. In the central part of the study area, a decrease in the IC is related to the proximity of the Monchique granitic rocks. In the second step, high-anchizone and epizone values are found. Mineral assemblages of pelitic rocks are similar for these two steps, with common intermediate $\mathrm{Na}-\mathrm{K}$ mica and more sporadic occurrences of paragonite. The final step is characterized by epizonetype values and by the absence of paragonite, with albite as the Na-rich mineral.

Direct measurements of crystallite thickness on lattice-fringe images (Fig. 8) confirm that both extremes of the first step actually present a mica similar in crystallinity (see above). Both these measures and the presence of paragonite-rich minerals indicate an anchizone grade, with the IC values being slightly affected by the enlargement of the $10 \AA$ A peak produced by the intermediate $\mathrm{Na}-\mathrm{K}$ mica and paragonite. Furthermore, an obvious thermal effect of the Monchique granitic pluton on the IC of shales of the Brejeira Formation can be seen in Figure 2. More extensive thermal overprinting than the aureoles delineated by visible hornfels are often present in the "isocrystallinity" maps of the British Geological Survey (Merriman \& Frey 1999).

The limits between the three IC steps described roughly coincide with the limits of the Mértola and Mira formations and the Phyllite-Quartzite and Pulo do Lobo formations. Nevertheless, the correspondence between the stratigraphic and metamorphic limits could be different in other cross-sections of the SPZ (Munhá 1983a).

Mata et al. (1998) have interpreted the variable presence of kaolinite throughout the SPZ sequence and of smectite only in its higher-grade zone (Fig. 2) as the result of "retrograde diagenesis". A similar situation was described in Permian-Triassic red slates of the Maláguide Complex in the Betic Cordillera, Spain by Nieto et al. (1994) and in Precambrian Freda sandstones, Wisconsin by Zhao et al. (1999).

The low phengite content of the K-rich dioctahedral mica, as determined both from the $b$ parameter (8.9779.005) $\AA$ and direct TEM analyses (Table 3 ), is characteristic of low-pressure regional metamorphism, developed in a thin-skinned fold-and-thrust-type orogen, as recently interpreted in the SPZ by several authors (Silva et al. 1990, Quesada et al. 1991, 1994, AlonsoChaves et al. 1999). Thrusts are usually associated with the reverse limbs of tight folds and produce imbrication between units with different structural and metamorphic 
characteristics. The thrust stacking of several distinct tectonic units produces a pattern with younger lithological formations toward the southwest. Sharp limits between the various values of IC characteristic of each stratigraphic formation are therefore interpreted as being associated with major tectonic boundaries.

\section{ConCluding Remarks}

The evolution from diagenesis to the greenschist facies in the phyllosilicates of the metapelites of SPZ is characterized by quantitative changes regarding the thickness of crystal domains and the number of defects. No qualitative changes are detected at grades lower than epizone. This situation agrees well with previous studies of other very-low-grade metamorphic sequences (Merriman \& Peacor 1999). The chemical composition of phyllosilicates is highly heterogeneous at the sample level, and it shows only a limited tendency to homogenization with an increase in metamorphic grade. This homogenization also includes a decrease in the magnitude of the illite compositional vector of micas. Muscovite, intermediate $\mathrm{Na}-\mathrm{K}$ micas and paragonite commonly coexist in samples of anchizone grade.

The crystallinity index of illite reflects the evolution of the thickness of crystallites with grade. In the SPZ, an increase in metamorphic grade from southwest to northeast is obvious, but it is not gradual owing to the effect of the fold-and-thrust tectonic organization, which produces the stepwise superposition of different tectonostratigraphic units.

\section{ACKNOWLEDGEMENTS}

We thank Carl Henderson and Dr. Donald R. Peacor of the University of Michigan for help with the SEMTEM study, and M.M. Abad Ortega from the Scientific Instrument Center of the University of Granada for her help with HRTEM work. We are also grateful to Christine Laurin for revising the English text. Thanks are extended to P. Schiffman, H. Vali and R.F. Martin for their critical reviews and helpful comments. The TEM study has been supported by NSF grant EAR-9418108. Financial support was also supplied by Research Project $\mathrm{n}^{\circ}$ BT2000-0582 and FPI research grant to I.A., both from the Spanish Ministry of Science and Technology and Research Group RNM-0179 of the Junta de Andalucía.

\section{REFERENCES}

Ahn, Jung-Ho \& Peacor, D.R. (1986): Transmission and analytical electron microscopy of the smectite-to-illite transition. Clays Clay Minerals 34, 165-179.

Alonso Chaves, F.M., García-Navarro, E. \& CAmacho, M.A. (1999): Deformación progresiva de la Zona Sudportuguesa: plegamiento y cizallamiento de secuencias multicapa. Geogaceta 25, 11- 15.
Árkai, P., Balogh, K. \& Frey, M. (1997): The effects of tectonic strain on crystallinity apparent mean crystallite size and lattice strain of phyllosilicates in low-temperature metamorphic rocks. A case study from the Glarus overthrust, Switzerland. Schweiz. Mineral. Petrogr. Mitt. 77, $27-40$.

ClifF, G. \& Lorimer, G.W. (1975): The quantitative analysis of thin specimens. J. Microscopy 103, 203-207.

Dalla Torre, M., Livi, J.T.K., Veblen, D.R. \& Frey, M. (1996): White K-mica evolution from phengite to muscovite in shales and shale matrix melange, Diablo Range, California. Contrib. Mineral. Petrol. 123, 390-405.

De Caritat, P., Hutcheon, I. \& Walshe, J.L. (1993): Chlorite geothermometry - a review. Clays Clay Minerals 41, 219239.

Essene, E.J. \& PeAcor, D.R. (1995): Clay mineral thermometry: a critical perspective. Clays Clay Minerals 43, 540553.

FREY, M. (1987): Very low-grade metamorphism of clastic sedimentary rocks. In Low Temperature Metamorphism (M. Frey, ed.). Blackie, Glasgow, U.K. (9-58).

Giorgetti, G., Memmi, I. \& Peacor, D.R. (2000): Retarded illite crystallinity caused by stress-induced sub-grain boundaries in illite. Clay Mineral. 35, 693-708.

Guidotti, C.V., Mazzoli, C., Sassi, F.P. \& Blencoe, J.G. (1992): Compositional controls on the cell dimensions of $2 M_{1}$ muscovite and paragonite. Eur. J. Mineral. 4, 283-297.

\& SASSI, F.P. (1998): Petrogenetic significance of $\mathrm{Na}-\mathrm{K}$ white mica mineralogy: recent advances for metamorphic rocks. Eur. J. Mineral. 10, 815-854.

Jiang, Wei-Teh \& Peacor, D.R. (1993): Formation and modification of metastable intermediate sodium potasium mica, paragonite, and muscovite in hydrothermally altered metabasites from northern Wales. Am. Mineral. 78, 782793.

, Merriman, R.J. \& Roberts, B. (1990): Transmission and analytical electron microscopic study of mixed layer illite/smectite formed as an apparent replacement product of diagenetic illite. Clays Clay Minerals 38, 449-468.

KISCH, H.J. (1987): Correlation between indicators of very lowgrade metamorphism. In Low Temperature Metamorphism (M. Frey, ed.). Blackie, Glasgow, U.K. (227-300).

(1991): Illite crystallinity: recommendations on sample preparation, X-ray diffraction settings, and interlaboratory samples. J. Metamorph. Geol. 9, 665-670.

KretZ, R. (1983): Symbols for rock-forming minerals. Am. Mineral. 68, 277-279.

LeE, J.H., Peacor, D.R., Lewis, D.D. \& Witsch, R.P. (1986): Evidence for syntectonic crystallization for the mudstone 
to slate transition at Lehigh Gap, Pennsylvania, U.S.A. $J$. Struct. Geol. 8, 767-780.

Leistel, J.M., MarcouX, E., ThiéBlemont, D., Quesada, C., Sánchez, A., Almodóvar, G.R., Pascual, E. \& SÁEZ, R. (1998): The volcanic-hosted massive sulfide deposits of the Iberian Pyrite Belt. Mineral. Deposita 33, 2-30.

Li, Gejing, Peacor, D.R., Buseck, P.R. \& Árkai, P. (1998): Modification of illite-muscovite crystallite-size distributions by sample preparation for powder XRD analysis. Can. Mineral. 36, 1435-1451.

Merriman, R.J. \& Roberts, B. (1994): The diagenetic to low grade metamorphism evolution of matrix white micas in the system muscovite-paragonite in a mudrock from central Wales, United Kingdom. Clays Clay Minerals 42, 369-381.

Lindgreen, H., Jacobsen, H. \& JaKobSEn, H.J. (1991): Diagenetic structural transformations in North Sea Jurassic illite-smectite. Clays Clay Minerals 39, 54-69.

Livi, K.J.T., Veblen, D.R., FerRy, J.M. \& Frey, M. (1997): Evolution of 2:1 layered silicates in low-grade metamorphosed Liassic shales of central Switzerland. J. Metamorph. Geol. 15, 323-344.

LotZE, F. (1945): Zur Gliederung der Varisciden der Iberischen Meseta. Geotekt. Forsch. 4, 78-92.

Mata, P., Bauluz, B., Nieto, F. \& Peacor, D.R. (1998): Apparent inconsistencies in prograde sequences of the Iberian Peninsula determined by XRD: effects of retrograde diagenesis. Thirty-fifth Annual Meeting of Clay Minerals Society (Cleveland), 61 (abstr.).

Merriman, R.J. \& Frey, M. (1999): Patterns of very low-grade metamorphism in metapelitic rocks. In Low GradeMetamorphism (M. Frey \& D. Robinson, eds.). Blackwell Science, Oxford, U.K. (61-107).

\& PEACOR, D.R. (1999): Very low-grade metapelites: mineralogy, microfabrics and measuring reaction progress. In Low Grade-Metamorphism (M. Frey \& D. Robinson, eds.). Blackwell Science, Oxford, U.K. (10-60).

\& RoberTs, B. (1985): A survey of white mica crystallinity and polytypes in pelitic rocks of Snowdonia and Llyn, north Wales. Mineral. Mag. 49, 305-319.

PeACor, D.R. \& Hirons, S.R. (1995): Strain-related differences in the crystal growth of white mica and chlorite: a TEM and XRD study of the development of metapelitic microfabrics in the Southern Uplands thrust terrane, Scotland. J. Metamorph. Geol. 13, 559-576.

MunhÁ, J. (1983a): Low-grade regional metamorphism in the Iberian Pyrite Belt. Comun. Serv. Geol. Portugal 69, 3-35.

(1983b): Hercynian magmatism in the Iberian Pyrite Belt. Mem. Serv. Geol. Portugal 29, 39-81.
(1990): Metamorphic evolution of the South Portuguese/Pulo do Lobo zone. In Pre-Mesozoic Geology of Iberia (R.D. Dallmeyer \& E. Martínez García, eds.). Springer, Berlin, Germany (363-368).

\& KERRICH, R. (1980): Sea water-basalt interaction in spilites of the Iberian Pyrite Belt. Contrib. Mineral. Petrol. 73, 191-200.

Oliveira, J.T., Ribeiro, A., Oliveira, V., QuesadA, C. \& Kerrich, R. (1986): Beja-Acebuches ophiolite: characterization and geodynamic significance. Bol. Soc. Geol. Portugal 2-13, 31.

Nieto, F. (1997): Chemical composition of metapelitic chlorites: X-ray diffraction and optical property approach. Eur. J. Mineral. 9, 829-841.

Ortega-Huertas, M., Peacor, D.R. \& Arostegui, J. (1996): Evolution of illite/smectite from early diagenesis through incipient metamorphism in sediments of the Basque-Cantabrian Basin. Clays Clay Minerals 44, 304323

Velilla, N., Peacor, D.R. \& Ortega-Huertas, M. (1994): Regional retrograde alteration of subgreenschist facies chlorite to smectite. Contrib. Mineral. Petrol. 115, 243-252.

OLIVEIRA, J.T. (1990): South Portuguese Zone: stratigraphy and synsedimentary tectonism. In Pre-Mesozoic Geology of Iberia (R.D. Dallmeyer \& E. Martínez García, eds.). Springer, Berlin, Germany (334-347).

Horn, M. \& PAPRoth, E. (1979): Preliminary note on the stratigraphy of the Baixo Alentejo Flysch Group, Carboniferous of southern Portugal and on the palaeogeographic development, compared to corresponding units in northwest Germany. Comunic. Serv. Geol. Portugal 65, 151-168.

QUESADA, C. (1991): Geological constraints on the Palaeozoic tectonic evolution of the tectonostratigraphic terranes in the Iberian Massif. Tectonophys. 185, 225-245.

(1998): A reappraisal of the structure of the Spanish segment of the Iberian Pyrite Belt. Mineral. Deposita 33, $31-44$.

Bellido, F., Dallmeyer, R.D., Gil-Ibarguchi J.I., Oliveira, J.T., Perez Estaun, A., Ribeiro, A., RoBARDET, M. \& Silva, J.B. (1991): Terranes within the Iberian Massif: correlations with West African sequences. In The West African Orogens and Circum-Atlantic Correlations (R.D. Dallmeyer \& J.P. Lécorché, eds.). Springer, Berlin, Germany (267-293).

Fonseca, P.E., Munhá, J., Oliveira, J.T. \& RIBEIRO, A. (1994): The Beja-Acebuches Ophiolite (southern Iberian Variscan fold belt): geological characterization and geodynamic significance. Bol. Geol. Mineral. Esp. 105, 3-49. 
Rausell-Colom, J.A., WiewióRA, A. \& MatesanZ, E. (1991): Relationship between composition and $\mathrm{d}_{001}$ for chlorite. Am. Mineral. 76, 1373-1379.

REY, J.P. \& KÜBLER, B. (1983): Identification des micas des séries sédimentaires par diffraction $\mathrm{X}$ à partir de la série harmonique (001) des préparations orientées. Schweiz. Mineral. Petrogr. Mitt. 63, 13-36.

Rieder, M., Cavazzini, G., D'Yakonov, Yu.S., FrankKamenetski, V.A., Gottardi, G., Guggenheim, S., Koval, P.V., Müller, G., Neiva, A.M.R., Radoslovich, E.W., Robert, J.-L., Sassi, F.P., Takeda, H., Weiss, Z. \& Wones, D.R. (1998): Nomenclature of the micas. Can. Mineral. 36, 905-912.

SASSI, F.P. \& SCOLARI, A. (1974): The $b_{0}$ value of the potassic white micas as a barometric indicator in low-grade metamorphism of pelitic schists. Contrib. Mineral. Petrol. 45, 143-152.

SCHERMERHORN, L.J.G. (1971): An outline stratigraphy of Iberian Pyrite Belt. Bol. Geol. Mineral. España 82, 23-52.

Shata, S. \& HeSSE, R. (1998): A refined XRD method for the determination of chlorite composition and applications to the McGerrigle Mountains anchizone in the Quebec Appalachians. Can. Mineral. 36, 1525-1546.

Silva, J.B., Oliveira, J.T. \& Ribeiro, A. (1990): South Portuguese Zone: structural outline. In Pre-Mesozoic
Geology of Iberia (R.D. Dallmeyer \& E. Martínez García, eds.). Springer, Berlin, Germany (348-362).

TAYLOR, S.R. \& MCLENNAN, S.M. (1985): The Continental Crust: its Composition and Evolution. Blackwell, Oxford, U.K.

WARR, L.N. \& NiETo, F. (1998): Crystallite thickness and defect density of phyllosilicates in low-temperature metamorphic pelites: a TEM and XRD study of claymineral crystallinity-index standards. Can. Mineral. 36, 1453-1474.

\& RICE, A.H.N. (1994): Interlaboratory standardization and calibration of clay mineral crystallinity and crystallite size data. J. Metamorph. Geol. 12, 141-152.

Zane, A., SAssi, R. \& GuidotTi, C.V. (1998): New data on metamorphic chlorite as a petrogenetic indicator mineral, with special regard to greenschist-facies rocks. Can. Mineral. 36, 713-726.

Zhao, G., Peacor, D.R. \& McDowell, S.D. (1999): "Retrograde diagenesis" of clay minerals in the Precambrian Freda Sandstone, Wisconsin. Clays Clay Minerals 47, 119-130.

Received February 21, 2001, revised manuscript accepted August 30, 2001. 